NEIDE PENA COTO

\title{
AVALIAÇÃO DE PROTETOR NASAL PARA ATIVIDADES DESPORTIVAS: ANÁLISE POR ELEMENTOS FINITOS
}

São Paulo

2009 


\section{Neide Pena Coto}

\section{Avaliação de protetor nasal para atividades desportivas:}

\section{análise por elementos finitos}

Tese apresentada à Faculdade de Odontologia da Universidade de São Paulo, para obter o título de Doutor, pelo Programa de Pós-Graduação em Odontologia.

Área de Concentração: Materiais Dentários

Orientadora: Profa. Dra. Josete Barbosa Cruz Meira

Co-Orientador: Prof. Dr. Reinaldo Brito e Dias

São Paulo 
Catalogação-na-Publicação

Serviço de Documentação Odontológica

Faculdade de Odontologia da Universidade de São Paulo

Coto, Neide Pena

Avaliação de protetor nasal para atividades desportivas: análise por elementos finitos / Neide Pena Coto; orientador Josete Barbosa Cruz Meira, co-orientador Reinaldo Brito e Dias. -- São Paulo, 2009.

84 p. : fig., tab.; $30 \mathrm{~cm}$.

Tese (Doutorado - Programa de Pós-Graduação em Odontologia. Área de Concentração: Materiais Dentários) -Faculdade de Odontologia da Universidade de São Paulo.

1. Protetor nasal flexível - Avaliação 2. Equipamentos de segurança - Esporte 3. Proteção pessoal - Protetor nasal flexível 4. Osso nasal - Esportes - Proteção 5. Materiais Dentários

AUTORIZO A REPRODUÇÃO E DIVULGAÇÃO TOTAL OU PARCIAL DESTE TRABALHO, POR QUALQUER MEIO CONVENCIONAL OU ELETRÔNICO, PARA FINS DE ESTUDO E PESQUISA, DESDE QUE CITADA A FONTE E COMUNICADA AO AUTOR A REFERÊNCIA DA CITAÇÃO.

São Paulo,

Assinatura:

E-mail: 


\section{FOLHA DE APROVAÇÃO}

Coto NP. Avaliação de protetor nasal para atividades desportivas: análise por elementos finitos [Tese de Doutorado]. São Paulo: Faculdade de Odontologia da USP; 2009.

São Paulo, /2009

\section{Banca Examinadora}

1) $\operatorname{Prof}(\mathrm{a}) \cdot \operatorname{Dr}(\mathrm{a})$.

Titulação:

Julgamento:

Assinatura:

2) $\operatorname{Prof}(\mathrm{a}) \cdot \operatorname{Dr}(\mathrm{a})$.

Titulação:

Julgamento:

Assinatura:

3) $\operatorname{Prof}(a) . \operatorname{Dr}(a)$.

Titulação:

Julgamento:

Assinatura:

4) $\operatorname{Prof}(a) . \operatorname{Dr}(a)$.

Titulação:

Julgamento:

Assinatura:

5) $\operatorname{Prof}(a)$. Dr(a).

Titulação:

Julgamento:

Assinatura: 


\section{DEDICATÓRIA}

Dedico este trabalho a minha única filha, Maria Júlia:

Filha, que fique o exemplo de luta, determinação, busca pelos

ideais, da curiosidade pelo desconhecido, de bem viver, de saber respeitar e amar ao próximo, enfim...

MINHA MAIS PERFEITA CRIAÇÃO!

Que fique o exemplo maior...

SER FELIZ! 


\section{AGRADECIMENTOS ESPECIAIS}

A DEUS que direcionou meus passos e orquestrou os contatos deste trabalho multidisciplinar e multicêntrico.

A minha orientadora, Profa. Dra. Josete Barbosa Cruz Meira que aceitou a empreitada mesmo em período de gestação do meu queridinho Gabriel e mãe ainda da pequena Mariana, meu xodó, o meu muito obrigada e que DEUS abençoe seu caminho e essa linda família.

Ao meu co-orientador Prof. Dr. Reinaldo Brito e Dias, que tem as idéias e os questionamentos que, procuramos sempre juntos responder através de pesquisas como esta. Sem ele este trabalho simplesmente não existiria.

A Profa. Dra. Larissa Driemeier da Escola Politécnica da USP que literalmente abriu portas para este trabalho. Porta da sua sala no dia que a procurei com um projeto audacioso; do Grupo de Mecânica dos Sólidos e de Impacto em Estruturas, onde executamos os passos mecânicos e as análises em elementos finitos. Espero poder contar sempre com sua solicitude e amizade.

Ao Centro Tecnológico da Informação CTI - Renato Archer nas pessoas do Prof. Dr. Jorge Vicente Lopes da Silva e do Prof. Dr. Pedro Yoshito Noritomi por disponibilizar as imagens e os protótipos usados neste estudo, além da parceria na troca de conhecimentos que, espero, seja duradoura. 
Mais uma vez a FEI (Fundação Educacional Inaciana Padre Sabóia de Medeiros) que nas pessoas do Prof. Ricardo Aurélio Costa e da Sra. Adelaide Bispo que auxiliou esta pesquisa no entendimento do EVA e na confecção de corpos de prova.

Ao Programa de Pós Graduação de Materiais Dentários da FOUSP, na figura da Profa. Dra. Rosa Helena Miranda Grande, que abraçou este projeto e permitiu sua execução.

A secretária do Departamento de Cirurgia, Prótese e Traumatologia Maxilo Faciais da FOUSP, Belira de Carvalho, pela sempre colaboração e amizade. 


\section{AGRADECIMENTOS}

Aos meus irmãos José Manuel, Maria Isabel e Matilde; ao José Tadeu e Eliomar que são cunhados com amor de irmãos; aos meus sobrinhos Ana Carolina, Manuela, Eduardo, Vinicius e Diego, minhas grandes paixões. A Matriarca, Maria Dolores, a tradução exata do dito popular "pau para toda a obra"; e ao meu pai José Manuel que não faz mais parte deste mundo, mas tenho a certeza que está entre nós.

Ao Professor Titular do Departamento de Materiais Dentários, Rafael Yague Ballester pelos grandes ensinamentos.

Aos professores do Departamento de Materiais Dentários da FOUSP pelo apoio.

A Profa.Dra. Beatriz Silva Câmara Mattos pela cessão do banco de dados de imagens.

Aos professores do Departamento de Cirurgia, Prótese e Traumatologia Maxilo Faciais da FOUSP pelo incentivo.

Ao aluno de Iniciação Científica da POLI USP Guilherme de Oliveira Roveri pelo empenho e interesse para a realização deste trabalho. 
Ao aluno de Iniciação Científica do CTI Renato Archer César Augusto Rocha Laureti pela parceria e empenho no trato com as imagens.

Ao mestrando da POLI USP André Sakai Gomes pelo apoio.

Ao doutorando da POLI USP Rafael Traldi Moura pela colaboração.

Ao aluno de Iniciação Cientifica da FOUSP Thiago Pereira Ramalho pelo apoio e interesse.

Aos alunos de Iniciação Científica Luci Alves, Ivan Gialain e Rodrigo Paiva da Disciplina de Prótese Buco Maxilo Facial da FOUSP, pela amizade.

Aos meus colegas da pós-graduação, pelo companheirismo.

Aos técnicos do laboratório do Departamento de Matérias Dentários Antonio Carlos Lascala e Silvio Peixoto Soares, assim como técnicos Paulo Sérgio Andremarchi e Carlos de Falco, do Departamento de Cirurgia, Prótese e Traumatologia Maxilo Faciais da FOUSP pela sempre e pronta colaboração.

As secretárias do Departamento de Matérias Dentários Elidamar Clementino Guimarães e Rosa Cristina Nogueira pelo carinho e orientações.

A TODOS os servidores não docentes dos Departamentos de Materiais Dentários e Cirurgia, Prótese e Traumatologia Maxilo Faciais da FOUSP, 
Departamento de Mecatrônica e Laboratório de Impacto em Estruturas da POLI USP, da Biblioteca da FOUSP e funcionários do CTI Renato Archer/Campinas o meu MUITO OBRIGADA!!!! 
DEUS ENVIA OS VENTOS, MAS É O HOMEM QUE DEVE IÇAR AS VELAS.

Santo Agostinho (354-430) 
Coto NP. Avaliação de protetor nasal para atividades desportivas: análise por elementos finitos [Tese de Doutorado]. São Paulo: Faculdade de Odontologia da USP; 2009.

\section{RESUMO}

Nos últimos anos notou-se um aumento significativo no número de fraturas faciais em atividades desportivas. Como o osso nasal está na zona de fragilidade da face, é um dos mais afetados por acidentes desportivos. Uma das soluções para evitar a fratura ou refratura é usar um protetor nasal na prática desportiva. Até o presente momento não existe nenhuma normatização em relação à confecção de protetores nasais para esporte. Além disso, não há estudo sistemático que tenha avaliado o desenho e a combinação de materiais em protetores nasais. A hipótese deste trabalho é que uma proteção eficiente é conseguida com protetores nasais confeccionados com uma lâmina de EVA (copolímero de etileno e acetato de vinila) flexível de dois milímetros sobreposta por uma lâmina de EVA rígida de um milímetro (chamado aqui de P1). Para verificar esta hipótese foi realizado estudo através de análise em elementos finitos. O EVA flexível é um material hiperelástico, que obedece ao modelo de Ogden, já o EVA rígido obedece ao modelo de Von Mises. Para utilização desses modelos várias constantes precisaram ser determinadas com auxílio de testes mecânicos de compressão. Para o tecido mole (também modelado como Ogden) e osso (modelo elástico linear) foram utilizados parâmetros da literatura. Uma vez determinadas as constantes para os modelos dos materiais envolvidos, foi possível comparar a eficiência do protetor nasal proposto em modelo de geometria mais complexa, representativa da realidade, obtida através de escaneamento e tomografia computadorizada. Para que a resposta virtual em 
elementos finitos simule a realidade de uma situação de impacto, a análise foi, ainda, não-linear e dinâmica. Os resultados mostraram que a hipótese foi confirmada, o protetor nasal P1 mostrou ser eficiente para a proteção dos ossos nasais.

Palavras-Chave: Protetor, Traumatismo nos esportes, Proteção nos esportes 
Coto NP. Evaluation of nasal guard for sports activities: finite element analysis [Tese de Doutorado]. São Paulo: Faculdade de Odontologia da USP, 2009.

\section{ABSTRACT}

In recent years there has been an increase in the number of facial fractures in sports activities. As the nasal bone is in the weakness zone of the face, is one of the most affected by sports accidents. One of the solutions to avoid fracture or refracture is to use a nose guard when practicing sports. Up to date there is no standardization in relation to the manufacture of nasal guards for sports. Moreover, there is no systematic study evaluating the design and combination of materials in nasal guards. The hypothesis of this work is that effective protection is achieved with nasal guards made of a two-millimeter flexible sheet of EVA (ethylene vinyl acetate) overlaid by an

one-millimeter layer of rigid EVA(here called P1). To verify this hypothesis a study was accomplished through finite element analysis. The flexible EVA is a hyperelastic material, which follows Ogden's model, while the rigid EVA follows Von Mises' model. In order to use these models, several constants had to be determined with the aid of mechanical compression tests. For soft tissue (Ogden model) and bones (linear elastic model) the necessary constants were obtained from literature. Once determined the constants for all considered materials, it was possible to compare the efficiency of the proposed nasal guard with a more complex geometry model, representative of reality, achieved by scans and tomography. In order to obtain virtual finite element response that mimitate the real impact situation, the analyses were 
necessarily non-linear and dynamic. The results showed that the hypothesis was confirmed, the P1 nasal guard was effective for the protection of the nasal bones.

Keywords: Guard, trauma in sports, protection in sports 


\section{SUMÁRIO}

1 p.

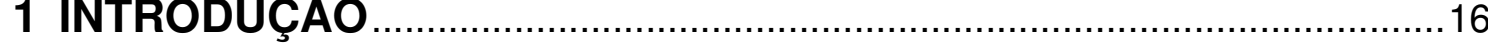

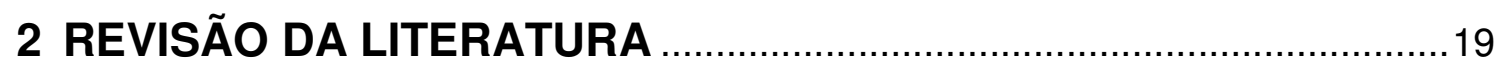

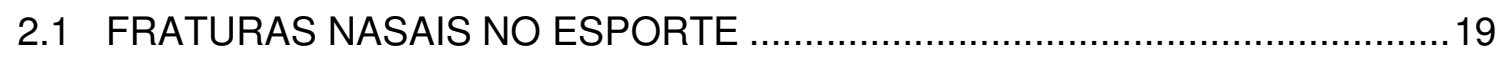

2.2 PROTETORES FACIAIS DE APLICAÇÃO NO ESPORTE ..............................23

2.3 ESTUDO DE FRATURAS ÓSSEAS ATRAVÉS DE ANÁLISE POR

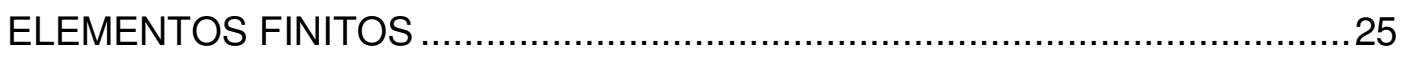

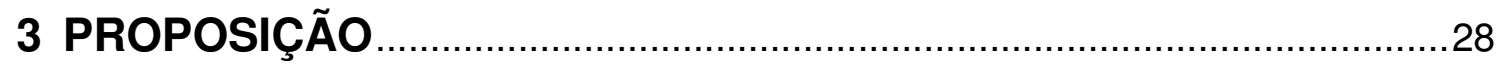

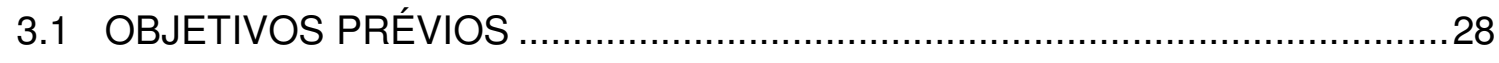

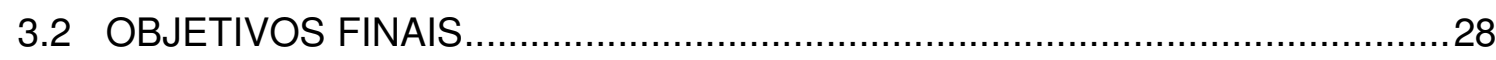

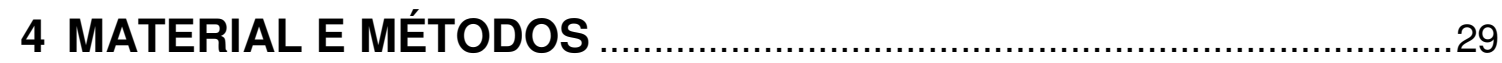

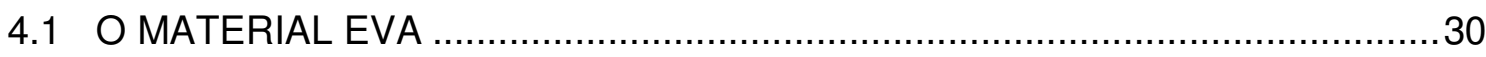

4.2 DETERMINAÇÃO DAS CONSTANTES DE OGDEN DO EVA FEXÍVEL ..........31

4.3 DETERMINAÇÃO DAS CONSTANTES DE VON MISSES PARA O EVA

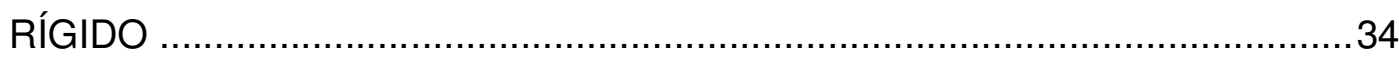

4.4 OBTENÇÃO DAS CONSTANTES DOS OSSOS DA FACE …….....................34

4.5 OBTENÇÃO DAS CONSTANTES DO TECIDO MOLE DA FACE ….................36

4.6 OBTENÇÃO DO MODELO CRÂNIO-FACIAL DIGITALIZADO PARA AEF ......37

4.7 AVALIAÇÃO DO PROTETOR NASAL EM AEF ..........................................40

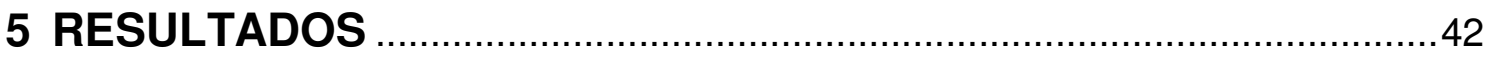

5.1 DETERMINAÇÃO DAS CONSTANTES DE OGDEN DO EVA FLEXÍVEL .......42

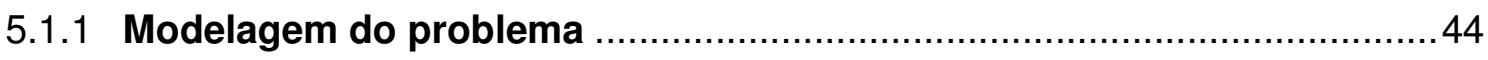


5.1.1.1Construção dos modelos numéricos ................................................ 45

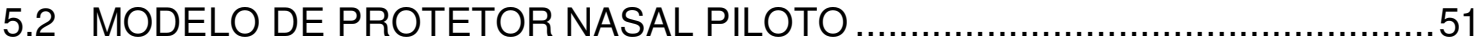

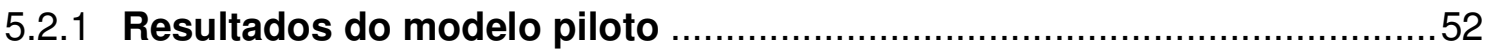

5.3 DETERMINAÇÃO DAS CONSTANTES DE VON MISES PARA O EVA

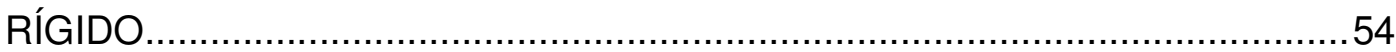

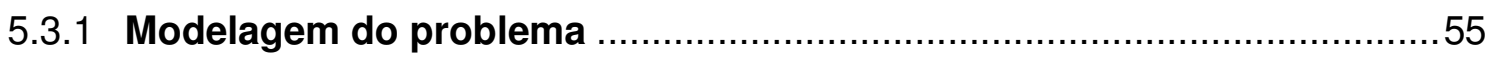

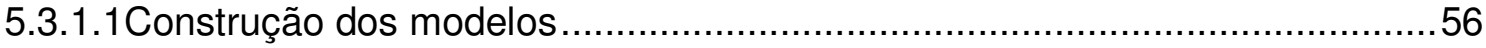

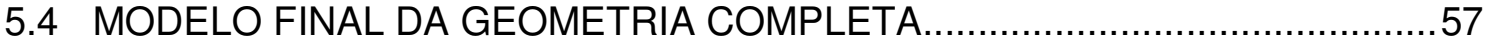

5.5 AVALIAÇÃO DO PROTETOR NASAL EM AEF ........................................... 62

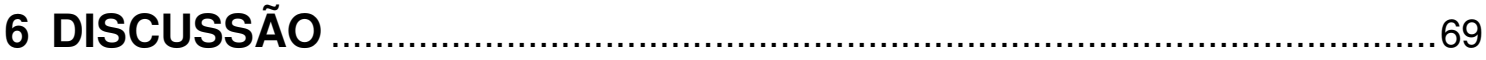

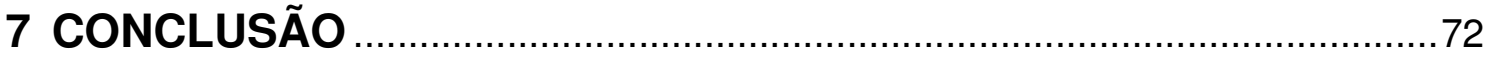

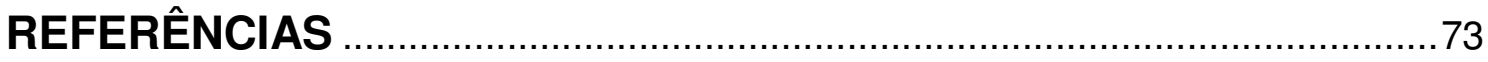

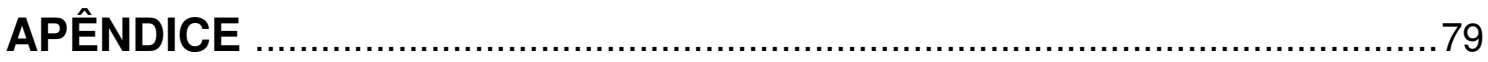

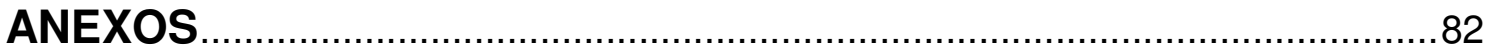




\section{INTRODUÇÃO}

Nos últimos anos notou-se um aumento significativo no número de fraturas faciais em atividades desportivas $(1,2)$. O osso nasal está na zona de fragilidade da face e encontra-se anteriorizado em relação às estruturas adjacentes, tornando-se assim um dos mais afetados por acidentes desportivos, cerca de $56 \%(3,4)$, especialmente nas modalidades rugby, futebol e basquete (5). Para uma boa reparação, o osso não pode sofrer deslocamentos durante o período de cicatrização. Assim, o atleta é muitas vezes afastado de treinos e competições por um longo período de tempo. Isso compromete a sua carreira e acarreta grande prejuízo financeiro para o Clube (6-10). Trabalhos mostram que 0 atleta perde condicionamento físico, além de apresentar, em muitos casos, tendência à depressão, o que prejudica sua recuperação física $(7,8)$.

Uma das soluções para evitar este afastamento é usar, durante a prática desportiva, um protetor nasal $(11,12)$. O protetor deve evitar que, durante um impacto, o osso em processo de reparação seja deslocado ou sofra refratura. O protetor também pode ser usado de forma preventiva em modalidades de alto risco de fraturas faciais (13). A geometria do protetor e os pontos de ancoragem na face devem garantir conforto para o atleta, para não comprometer o seu desempenho físico durante jogos e treinos. Além disso, é importante que o material a ser utilizado apresente boa capacidade amortecedora (14).

A característica amortecedora de um protetor nasal está relacionada à distribuição de energia, deformação do material e liberação de calor. Isto significa 
que a transmissibilidade de energia para as estruturas circunvizinhas torna-se baixa. Um material que se destaca neste requisito é o copolímero de etileno e acetato de vinila (EVA). O EVA é um polímero termoplástico, com grande aplicabilidade em indústria de calçados e pisos amortecedores, que tem se tornado o material preferido para confecção de protetores na área odontológica. Além da capacidade amortecedora, o EVA apresenta algumas vantagens como: conformação a baixa temperatura, facilidade de manipulação, reprodutibilidade, boa coesão entre camadas, transparência e baixo custo (15).

No mercado odontológico, o EVA apresenta-se sob a forma de placas planas rígidas e flexíveis, em espessuras de um a cinco milímetros ( $\mathrm{mm}$ ). A capacidade amortecedora do EVA está relacionada ao teor de acetato de vinila (quanto menor o teor, maior a capacidade de amortecimento). A rigidez do polímero interfere bastante no conforto do paciente. Placas mais flexíveis promovem maior conforto, deformam com muita facilidade, porém oferecem menor proteção. Assim, a associação de placas flexíveis e rígidas parece uma solução interessante para aperfeiçoar as propriedades do material.

Até o presente momento não existe nenhuma normatização em relação à confecção dos protetores nasais. Além disso, não há estudo sistemático que tenha avaliado o desenho e a combinação de materiais em protetores nasais.

A hipótese deste trabalho é que uma proteção eficiente é conseguida com protetores nasais confeccionados com uma lâmina de EVA flexível de dois milímetros sobreposta por uma lâmina de EVA rígida de um milímetro. Este protetor foi idealizado pela Disciplina de Prótese Buco Maxilo Facial da Faculdade de Odontologia da Universidade de São Paulo (FOUSP). 
Para verificar esta hipótese foi realizado estudo através de análise em elementos finitos neste protetor nasal, chamado aqui de P1. 


\section{REVISÃO DA LITERATURA}

\subsection{FRATURAS NASAIS NO ESPORTE}

A face é a região mais exposta do crânio, portanto mais sujeita a injúrias provocadas por impactos diretos como pancadas e golpes $(16,17)$, freqüentes em esportes de contato (5). Felizmente, o esqueleto da face é composto por ossos capazes de suportar altas forças de impacto, como os zigomáticos, frontal e mandíbula. Estes ossos assumem a função de proteger elementos vitais como cérebro, olhos e estruturas neuromusculares, formam assim a zona de resistência da face (18).

Ao dividir a face em terços, tem-se o terço superior (entre a sutura fronto nasal e a região mais superior do osso frontal), médio (entre a sutura fronto nasal e maxila) e inferior (entre comissura labial e parte mais antero - inferior da mandíbula). Apesar de o terço médio conter os ossos zigomáticos, que oferecem um arcabouço resistente, é o terço que apresenta a maior incidência de fraturas da face nos esportes. Esta maior incidência deve-se ao fato de o terço médio também conter a zona de fragilidade da face composta pela maxila e pelos ossos nasais $(19,20)$.

Os ossos nasais, finos e proeminentes em sua porção inferior, vêm recebendo atenção especial pelo grande índice de fraturas em atividades desportivas (cerca de 56\%)(3,4). Sendo que $15 \%$ delas são recorrentes (18). As fraturas nasais durante a prática esportiva tiveram um importante acréscimo nesses últimos 15 anos, devido o aumento em $40 \%$ de esportes em ambiente fechado (1). 
Dependendo da direção e força do impacto tem-se os tipos de fratura que pode envolver os ossos próprios do nariz, as cartilagens lateral superior e lateral inferior, assim como os ossos vizinhos (lacrimal, frontal, malar, etmóide e órbita), associado ou não a lesões de tecido mole $(10,21)$. Normalmente não ocorre fratura de septo, quando ocorre é classificada como subcategoria da fratura nasal (22).

O tratamento de uma fratura nasal tem início com sua redução cirúrgica $(9$, 23), que deve transcorrer nas primeiras duas ou três horas após a ocorrência da lesão (21), onde a respiração nasal deve ser restabelecida (24). Sua imobilização é feita através de gesso sobre o nariz em um período de sete a dez dias (25). Deve-se aguardar de quatro a sete dias para retorno a treinos e jogos onde o uso de protetor nasal é recomendado (18). Para uma boa reparação, os ossos nasais não podem sofrer deslocamentos durante o período de cicatrização (8). Sua consolidação ocorre em três estágios: de inflamação recente, de reparação e de remodelação, em um período de seis a dez semanas $(7,9,18,24)$, sendo que só após 30 dias da redução dá-se a união óssea perfeita (23).

A fratura nasal ocorre em três ocasiões: contra outro esportista, contra o solo e contra algum equipamento da quadra ou campo $(3,11)$, entretanto a causa mais comum de fratura nasal é o impacto contra outro jogador que chega a $43 \%$, seguido por impacto de cotovelo-cabeça e cabeça com cabeça (26),ocorre normalmente por colisão onde há o choque face com cabeça, face com parte do corpo. Devido a sua localização, mais exposta a injúrias (27), a fratura nasal é a terceira em ocorrência dos traumas desportivos, precedida pela fratura da clavícula e do punho (21).

As fraturas na região nasal são resultados de ação e reação, onde os ossos fraturam devido à tensão criada no local. Os fatores que influenciam a ação são: direção, duração, intensidade e ponto de aplicação da força; massa e forma do 
agente ofensivo; a reação é influenciada por: resistência e o módulo de elasticidade dos componentes mesofaciais (20).

Por definição o impacto é um fenômeno que ocorre em curta duração, na ordem de milisegundos (ms). Este fato traz idéias conflitantes entre os pesquisadores a respeito da participação dos músculos, articulações, movimentação da cabeça e pescoço e deformações dos tecidos moles na absorção da energia do impacto. Enquanto Hampson (28) considera os tecidos acima absorvedores de energia, outros estudos mostram que não ocorre resposta muscular em um tempo tão curto $(29,30)$.

Dentre as formas mais comuns de energia encontradas na natureza tem-se a energia cinética, característica dos corpos em movimento. A energia cinética recebida pelo corpo é transformada, em grande parte, em energia de deformação. A diferença entre essa energia de deformação e a capacidade de absorção do osso pode resultar em fratura (31).

O estudo da biomecânica do impacto oferece a possibilidade de prevenção de injúrias através da otimização e aperfeiçoamento de mecanismos de proteção (28, 32). Para tanto se deve saber que:

- A velocidade de impacto do cotovelo na cabeça é de 1,7 - 4,6 metros por segundo $(\mathrm{m} / \mathrm{s})(33)$.

- A duração média do impacto é 15 ms (16).

- A energia necessária para causar fratura dos ossos íntegros da face, como nariz e maxila, em um golpe frontal apresenta grande variação na literatura: 15Joules $(\mathrm{J})(34)$ ou de $25 \mathrm{~J}$ a $45 \mathrm{~J}(35)$ sendo que, quando a energia de impacto chega a 45J, pode causar concussão (36). 
- O tempo de duração do impacto é determinante para que ocorra a falha do osso, pois a força de reação cai com o aumento do tempo de duração do impacto (ver apêndice A). A porção mais fraca do osso nasal fratura com 342,5 Newtons (N) (29).

Um retorno antecipado após fratura nasal pode refraturar os ossos acometidos, tornando impossível uma cirurgia simples, sem deformidade nasal (18). Para evitar essa situação o atleta é muitas vezes afastado de treinos e competições por um longo período de tempo (8) e, esse afastamento pode comprometer sua carreira e acarretar grande prejuízo financeiro para o Clube (7). O atleta perde condicionamento físico, além de apresentar, em muitos casos, tendência à depressão, o que prejudica sua recuperação física (18).

Prevenir injúrias orofaciais é um grande investimento quando comparado ao desconforto e custo que uma fratura traz ao atleta e ao clube. Investir em protetores nasais e bucais reduz a freqüência e severidade das injurias orofaciais nos esportes e afastamento do atleta de treinos e competições. O protetor deve evitar que, durante um impacto, o osso, em processo de reparação, seja deslocado ou sofra refratura $(11,25)$. Técnicos e treinadores devem ser conscientizados sobre as vantagens do uso de protetores nasais. 


\subsection{PROTETORES FACIAIS DE APLICAÇÃO NO ESPORTE}

The National Youth Sports Foundation for the Prevention of Athletic Injuries afirma que o atleta quando não usa protetor nasal tem $45 \%$ de chance de fratura nasal(11).

Os protetores nasais e faciais atenuam e distribuem a energia de impacto pela face (12). Protetores orofaciais reduzem em $50 \%$ o total de fraturas orofaciais relatadas nos esportes, e o cirurgião dentista deve ser o profissional responsável pela sua confecção (5).

Segundo Associação Americana de Basquete os protetores nasais devem aproveitar a geometria de proteção da face isto é, reforçar suas zonas de resistência (ossos zigomáticos e frontal), minimizando a quantidade de energia que chega aos ossos nasais (10). A qualidade da proteção depende das propriedades mecânicas do material utilizado, do formato do protetor e suas aplicações. No impacto, a súbita transferência de energia cinética para o material pode provocar danos dependendo da extensão em que o material deforma (37). A compreensão do mecanismo de dano do material pode auxiliar para a melhoria da proteção dos protetores, considerando as condições adversas de uso e seus efeitos.

Diversos materiais são propostos para a confecção do protetor nasal, procurando sempre uma maior proteção e conforto.

Os polímeros são materiais muito interessantes para fabricação de protetores nasais, tanto do ponto de vista mecânico como pela facilidade de conformação a baixa temperatura. 
Entre os polímeros que são utilizados para confecção de protetores nasais pode-se citar: policarbonato $(11,24)$, resina acrílica (38), Aquaplast (23) e Plexiglas (38). Silicone e espuma também são utilizados em associação com policarbonato e resina acrílica, respectivamente, a fim de conferir conforto e evitar lesões aos tecidos adjacentes.

O copolímero de etileno e acetato de vinila (EVA) apresenta algumas vantagens como: conformação a baixa temperatura, facilidade de manipulação, reprodutibilidade, boa coesão entre camadas, transparência e baixo custo. O EVA tem ampla utilização como protetor pós-operatório em casos de distrações osteogênicas em mandíbula, pois previne trauma dos tecidos moles evitando ulcerações graves durante esse período (39). Apresenta característica de absorver energia, reduzir transmissão de impacto minimizando sua repercussão. Apresenta moldabilidade, durabilidade, facilidade de acabamento (14). Os danos observados após impacto são: deformação permanente, rasgo ou fratura e delaminação (37).

O EVA é indicado para a confecção de protetores bucais, nasais e faciais para esporte, pois apresenta grande capacidade de absorção de energia, sendo que sua espessura interfere diretamente nessa capacidade, quanto mais espesso mais energia absorve (40).

Independente o material utilizado, a manutenção da visão periférica é um requisito importante para garantir que o atleta não perca nenhum movimento ao seu redor, fundamental em seu desempenho (11).

Para a confecção dos protetores é necessária a moldagem da face, que é realizada com o auxilio de hidrocolóide irreversível (alginato), clipes de retenção ou gaze e gesso tipo I. O protetor é fixado na face com o auxílio de elásticos e velcro na região crânio occipital, o que permite ao atleta jogar sem comprometer a segurança 
dos outros atletas e sem interferir na visão periférica; seu recorte obedece as zonas de resistência da face como apoio no osso frontal e nos zigomáticos (25) ou com recorte seguindo a anatomia do osso frontal, zigomáticos e maxilar (38).

\subsection{ESTUDO DE FRATURAS ÓSSEAS ATRAVÉS DE ANÁLISE POR ELEMENTOS FINITOS}

Elementos finitos (EF) é uma ferramenta numérica para resolução de equações diferenciais. Essa ferramenta é amplamente utilizada na análise estrutural, uma vez que a equação de equilíbrio de um corpo deformável nada mais é do que uma complexa equação diferencial que possui solução exata e fechada somente para casos muito simples. Com a evolução dos computadores foi possível a criação de modelos cada vez maiores e mais complexos, de forma que, atualmente, pode-se recriar o comportamento real de uma estrutura virtualmente com grande precisão. Amplamente utilizado desde a década de 80 na engenharia, o Método dos Elementos Finitos (MEF) vem sendo cada vez mais importante dentro da área odontológica, para a determinação da distribuição das tensões e deformações decorrentes de forças aplicadas em sistemas estruturais como dente, osso e tecido $(32,41-43)$.

Em muitos casos práticos da área médica e odontológica, o MEF é a única ferramenta disponível, ainda que sob o ponto de vista matemático a solução seja considerada como uma aproximação, como é o caso de fraturas em ossos da face. Onde a pesquisa sobre o mecanismo de injúrias ocasionadas por impacto não é 
viável in vivo (42). O MEF pode ajudar a entender o mecanismo da injúria, quantificar mecanicamente os parâmetros específicos do impacto assim como formular sua tolerância. Porém, é importante ressaltar que resultados experimentais são sempre necessários para validar um modelo virtual. Esses resultados, porém, podem vir de experimentos similares ao da pesquisa, em condições técnicas e éticas apropriadas. A aplicação de cargas estáticas em crânios humanos, por exemplo, ajuda a determinar áreas críticas de suscetibilidade à lesão devido à proeminência e/ou fragilidade dos tecidos faciais. E com o aumento da confiabilidade da predição de modelos computacionais, podem-se reduzir esforços experimentais e aumentar a gama de condições pesquisadas (32).

Além disso, MEF é a ferramenta apropriada para estudar com mais precisão o ambiente de tensão-deformação para estruturas complexas como os ossos faciais (41). No caso de impacto, por exemplo, os parâmetros determinantes da resistência óssea são: intensidade e distribuição da força, duração do impacto, espessura, elasticidade e densidade do osso impactado.

Para uma análise de impacto em elementos finitos, além da geometria e condições de contorno, deve-se ter conhecimento das características do material estudado. Diz-se que essa análise de impacto na face é não linear. Existem três condições que podem gerar não linearidade de um problema:

- comportamento dos materiais, que seguem leis não lineares, diferentes da lei de Hooke elástica linear;

- as grandes deformações e/ou deslocamentos que ocorrem, de modo que o equilíbrio deve ser sempre calculado em uma posição atualizada;

- mudança das condições de contorno durante a evolução do problema. 
Dessa forma, o teste de impacto envolve as três não linearidades: as características do EVA (obtido por ensaios mecânicos), osso e tecido mole são não lineares; ocorrem grandes deformações no EVA flexível e tecido mole além do deslocamento do agente impactante; ocorre mudança das condições de contorno a partir do momento que este atinge a face.

Portanto, um problema de impacto na face pode ser resolvido somente através de uma análise explícita (solução numérica particularmente adequada a problemas de curta duração) não linear em elementos finitos, cuja solução é aproximada. 


\section{PROPOSIÇÃO}

\subsection{OBJETIVOS PRÉVIOS}

- Determinar as constantes de Ogden do EVA flexível;

- Determinar as constantes de Von Mises do EVA rígido;

- Obter modelo crânio facial para ser utilizado na AEF (Análise por Elementos Finitos).

\subsection{OBJETIVOS FINAIS}

- Observar a eficiência do protetor nasal, P1, em modelo crânio-facial, no método de elementos finitos. 


\section{MATERIAL E MÉTODOS}

Para o sucesso de um modelo em EF, além da geometria detalhada e condições de contorno, cada material envolvido tem um comportamento particular, regido pela sua lei constitutiva. Isto é, dentre os vários modelos de material disponíveis em softwares comerciais, deve-se selecionar aquele que melhor mimetiza o comportamento do material em questão.

Cada lei constitutiva é composta por parâmetros do material. Por exemplo, para a lei mais simples, elástico-linear, é necessário fornecer dois parâmetros: módulo de elasticidade e coeficiente de Poisson do material. Modelos mais complexos exigem maior número de parâmetros, como é o caso do material EVA.

Para este trabalho foram necessários os parâmetros do osso cortical, material linear elástico; do tecido mole, material hiperelástico; do EVA flexível, que obedece ao modelo matemático não linear de Ogden, e do EVA rígido, material que obedece ao modelo matemático de Von Mises. Para isso, várias constantes precisam ser determinadas com auxílio de testes mecânicos como tração, compressão e/ou impacto. Uma vez determinadas as constantes para o EVA rígido e flexível, foi possível comparar a eficiência do protetor nasal em modelo com geometrias mais complexas, representativas da realidade. Para que o modelo de elementos finitos seja representativo da realidade a ser simulada, a análise tem que ser necessariamente dinâmica e explícita. 
A análise por elementos finitos foi realizada pelo programa LS Dyna. Além disso, o programa Hyper Mesh foi utilizado para geração da malha, como préprocessador, e o Hyper View como pós-processador(44).

\subsection{O MATERIAL EVA}

Este material é um polímero termoplástico de estrutura semicristalina, sua geometria é composta por uma parte amorfa e outra parte cristalina. Como em qualquer polímero, as propriedades físicas do EVA dependem de sua massa, de seu formato e de sua geometria. O EVA é considerado um copolímero pelo fato de ser constituído por dois monômeros, o etileno e o acetato de vinila. O seu processamento permite uma porcentagem entre $18 \%$ e $28 \%$ de acetato de vinila. $\mathrm{A}$ capacidade amortecedora do EVA cresce conforme a porcentagem de acetato de vinila diminui, neste trabalho o EVA utilizado tem 19\% de acetato de vinila. O EVA é uma macromolécula composta por repetidas unidades unidas por ligações covalentes, suas unidades primárias de constituição são dois monômeros cujas propriedades físicas dependem do tamanho e do peso molecular dos mesmos. Materiais poliméricos geralmente apresentam baixa densidade, resistência à temperatura e condutividade térmica e elétrica. Entre as principais características do EVA pode-se destacar sua grande elasticidade, flexibilidade e boa tenacidade a baixas temperaturas, boa resistência mecânica e grande resistência à fratura. Considerando o EVA flexível, algumas propriedades, como elasticidade, são mais proeminentes, no entanto, outras propriedades como limite de resistência 
mecânica são mais baixos. O EVA flexível possui um comportamento semelhante aos elastômeros. Os termoplásticos são polímeros que podem amolecer e escoar quando sujeitos a altas temperaturas e pressões e fora desta situação, permanecem sólidos com geometria definida, sendo essa transformação reversível, por tal motivo ela podem ser chamado de fusíveis, solúveis e recicláveis. Na maioria das situações práticas nas quais os polímeros são aplicados ou testados mecanicamente, é possível observar que sua resposta mecânica é dependente do tempo, o que os aproxima dos materiais viscoelásticos. Ou seja, seu comportamento é similar ao comportamento de um fluído viscoso, dando respostas elásticas instantâneas. Essa parte que faz o polímero se comportar como um fluido viscoso consome parte da energia absorvida de forma irreversível. Essa absorção pode ocorrer devido ao atrito interno entre as macromoléculas, por mudanças de formas (rotação do carbono - ligações de carbono ao redor de seu próprio eixo) ou por seu escoamento. Além disso, se o esforço transferido ao polímero for repentino, o atraso da resposta elástica dependerá da diferença de tempo entre o estímulo e a resposta do polímero para a sua macromolécula enovelar e desenovelar. Este atraso na resposta mecânica ou elástica ocorre devido à sua porção viscosa.

\subsection{DETERMINAÇÃO DAS CONSTANTES DE OGDEN DO EVA FEXÍVEL}

A determinação das constantes do EVA foi conseguida através do método inverso de caracterização dos materiais, que consiste em tornar coincidentes as 
curvas carga $\mathrm{x}$ deslocamento de ensaios experimentais com suas respectivas simulações numéricas, através de ajuste das constantes do modelo de Ogden. Foram simulados testes mecânicos de tração e compressão.

Para cada um dos ensaios foi utilizada o EVA flexível simulado com o modelo hiperelástico de Ogden $(45,46)$, dado por:

$$
W^{*}=\sum_{i=1}^{3} \sum_{j=1}^{n} \frac{\mu_{j}}{\alpha_{j}}\left(\lambda_{i}^{* \alpha_{j}}-1\right)+\frac{1}{2} K(J-1)^{2}
$$

Onde:

$$
\begin{aligned}
& W=\text { equação derivada para cálculo de tensões, } \\
& n=\text { número de termos da série Ogden, } \\
& J=\text { parâmetros relacionados com mudanças de volume, } \\
& \mu=\text { parâmetros do modelo, } \\
& \alpha=\text { parâmetros para caracterização de curvas, } \\
& \lambda=\text { alongamento na direção principal, } \\
& K=\text { módulo volumétrico do material. }
\end{aligned}
$$

A geometria e dimensões dos espécimes de cada teste estão apresentadas na figura 4.1. Para a simulação do teste de tração, foi simulado apenas $1 / 4$ do espécime, devido à simetria geométrica e de carregamento. O número de elementos para cada teste foi de 4.000 para teste de tração e 5.700 para teste de compressão. 


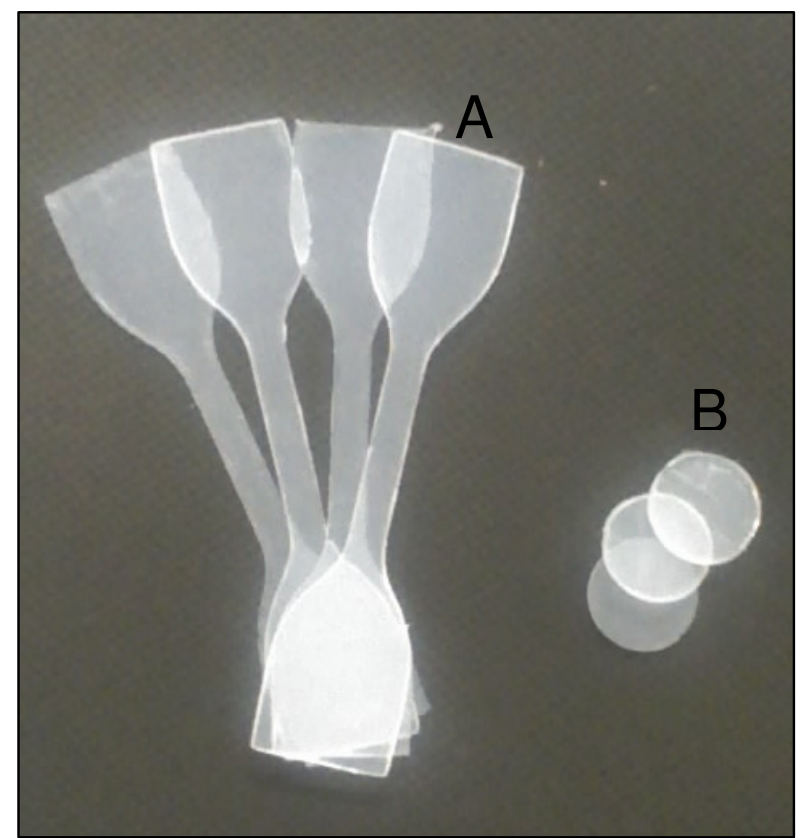

Figura 4. 1 - Geometria e dimensões dos espécimes utilizados para os ensaios de (A) tração, (B) compressão

Os testes foram acompanhados por filmagem através de câmera de alta velocidade Photron Ultima APX-RS (3000 frames por segundo) (47). A filmagem ajudou a estudar fenômenos não lineares que ocorrem com o EVA. A caracterização foi considerada eficiente quando houve semelhança entre a curva carga $x$ deformação obtida experimentalmente e por AEF, isso ocorreu com a curva de compressão. Os parâmetros utilizados para alimentar o modelo matemático de Ogden foram obtidos através da curva de compressão, uma vez que as injúrias da face ocorrem normalmente por colisão onde há deformações provocadas por forças compressivas (48). 


\subsection{DETERMINAÇÃO DAS CONSTANTES DE VON MISSES PARA O EVA RÍGIDO}

A determinação das constantes do EVA rígido, assim como o EVA flexível, foi conseguida através do método inverso de caracterização dos materiais. Foram simulados testes mecânicos de compressão.

A geometria e dimensões do espécime do teste estão apresentadas na figura 4.1B. O número de elementos para o teste foi de 1350 para teste de compressão.

Os testes foram acompanhados por filmagem através de câmera de alta velocidade Photron Ultima APX-RS. A caracterização foi considerada eficiente quando houve semelhança entre a curva carga $x$ deformação obtida experimentalmente e por AEF na curva de compressão. Assim como para o EVA flexível.

\subsection{OBTENÇÃO DAS CONSTANTES DOS OSSOS DA FACE}

No estudo da microestrutura óssea, para o entendimento das fraturas ósseas, o modelo adquirido através de tomografias computadorizadas tem uma grande especificidade, e seu critério de falha é o "modelo de dano perfeito" teoria viscoelastoplastica similar ao comportamento viscoelásticos não linear, a resposta da tensão é determinada por variável tempo dependente (41). 
O osso cortical é representado como material linear elástico, homogêneo e isotrópico com densidade $=7.85 \mathrm{E}-8$ toneladas por milímetro cúbico $\left(\mathrm{t} / \mathrm{mm}^{3}\right)$, módulo de elasticidade $=1300$ Mega Pascal $(\mathrm{MPa})$ e coeficiente de Poisson $=0.3(34,49$, 50). As propriedades mecânicas do osso são dependentes de sua composição (51). O pico de tensão de Von Mises para o osso cortical é de 236.3 kilo Pascal (kPa) (52).

A porção óssea da face de interesse neste estudo é formada pelos ossos frontal, nasal, zigomáticos e maxilar. Esta divisão foi aqui considerada, pois se encontra na literatura a resistência que cada osso suporta, como mostra a tabela 4.1 abaixo $(28,29)$.

Tabela 4. 1 - Resistência dos ossos da face de interesse neste estudo

\begin{tabular}{c|c|c|}
\hline \hline \multirow{2}{*}{ OSSOS } & $\begin{array}{c}\text { Resistência -Força } \\
(\mathbf{N})\end{array}$ & $\begin{array}{c}\text { Resistência - Pressão } \\
\left(\mathbf{N} / \mathbf{m m}^{2}\right)\end{array}$ \\
\hline Frontal & $1000-6494$ & $\geq 7,58$ \\
\hline Zigomáticos & $489-2401$ & $1,38-4,17$ \\
\hline Maxilar & $668-1801$ & $1,03-2,07$ \\
\hline Nasal & $342-450$ & $\mathbf{0 , 1 3 - 0 , 3 4}$ \\
\hline
\end{tabular}

Como condições de contorno, as extremidades do recorte do tecido ósseo têm os seis graus de liberdade (três translações e três rotações) restritos.

Quanto ao critério de falha dos tecidos ósseos alguns trabalhos apresentam a máxima tensão principal (53). Outros utilizam a tensão de Von Mises $(54,55)$ ou o microdano (41). Trabalhos mais recentes têm demonstrado que o melhor critério seria a máxima deformação equivalente $(47,56,57)$. 


\subsection{OBTENÇÃO DAS CONSTANTES DO TECIDO MOLE DA FACE}

O tecido mole é representado como um material não-linear hiperelástico (57), possui densidade $=9.5000 \mathrm{E}-10 \mathrm{t} / \mathrm{mm}^{3}$, coeficiente de Poisson $=0,3$ e módulo de cisalhamento $=0,69 \mathrm{MPa}(45,58,59)$.

As propriedades do sistema músculo-esquelético atraem muitas atenções, o modelo não linear elástico baseado na energia de deformação possui uma forma polinomial com coeficientes tempo dependentes (60). O tecido mole pode-se caracterizar como não-linear hiperelástico (57).

A espessura dos tecidos da face pode ser considerada constante para facilitar a AEF (56).

Neste trabalho optou-se por utilizar um modelo já consagrado pelo Comitê Europeu de Melhorias da Segurança de Veículos - EEVC/2004 (61) de forma a representar o comportamento biomecânico da cabeça. Um polímero elastômero foi indicado para simular o tecido mole (Figura 4.2). 


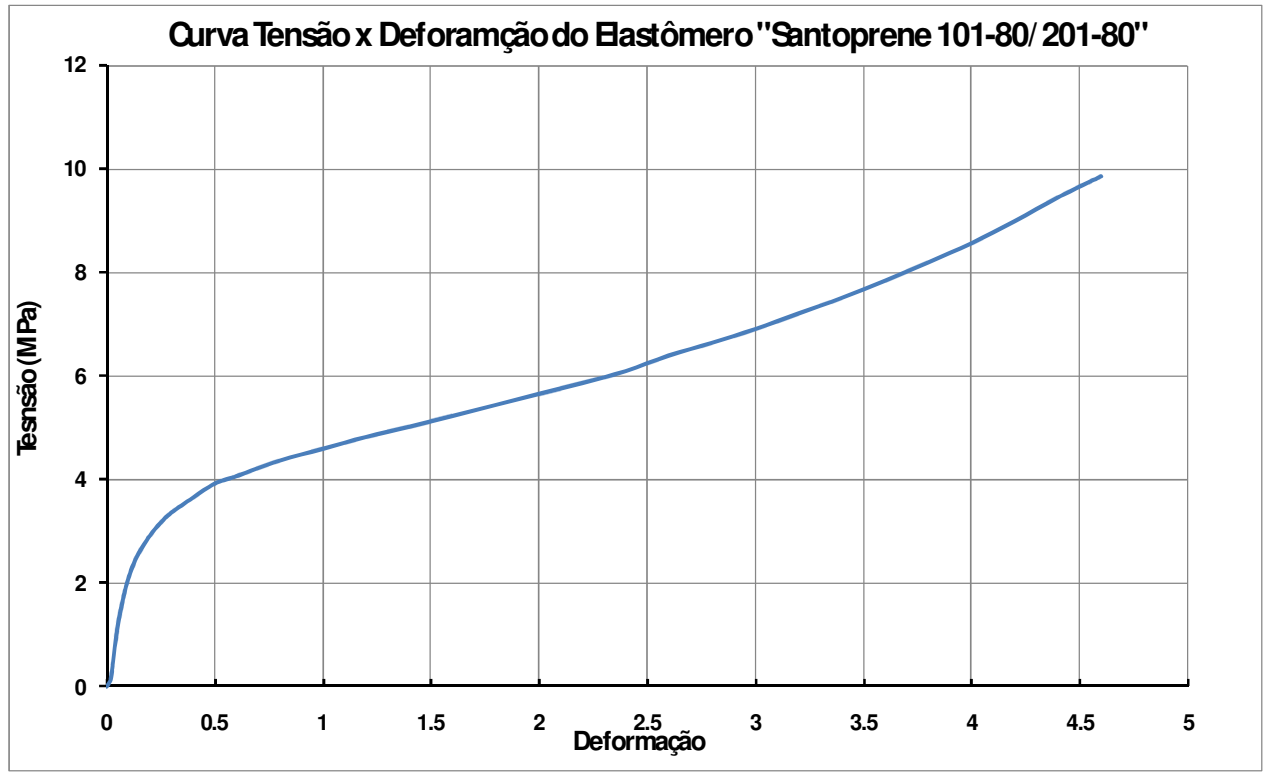

Figura 4. 2 - Curva tensão x deformação de engenharia do material elastômero utilizado para simular o tecido humano

\subsection{OBTENÇÃO DO MODELO CRÂNIO-FACIAL DIGITALIZADO PARA AEF}

Um modelo tridimensional (3D) da face humana foi desenvolvido para simular o comportamento mecânico do protetor nasal em EVA, submetido à carga de impacto. Um arquivo em formato Stereolithography (STL) obtido através de Tomografia Computadorizada (TC) da face foi doado pelo Centro de Tecnologia da Informação Renato Archer (CTI) (Anexos B e C) com a utilização das imagens aprovada pelo Comitê de Ética da FOUSP (Anexo A).

A figura 4.3 apresenta uma versão preliminar da imagem. Recortes foram necessários para considerar a estrutura de ossos que trabalham em conjunto com algumas particularidades. 


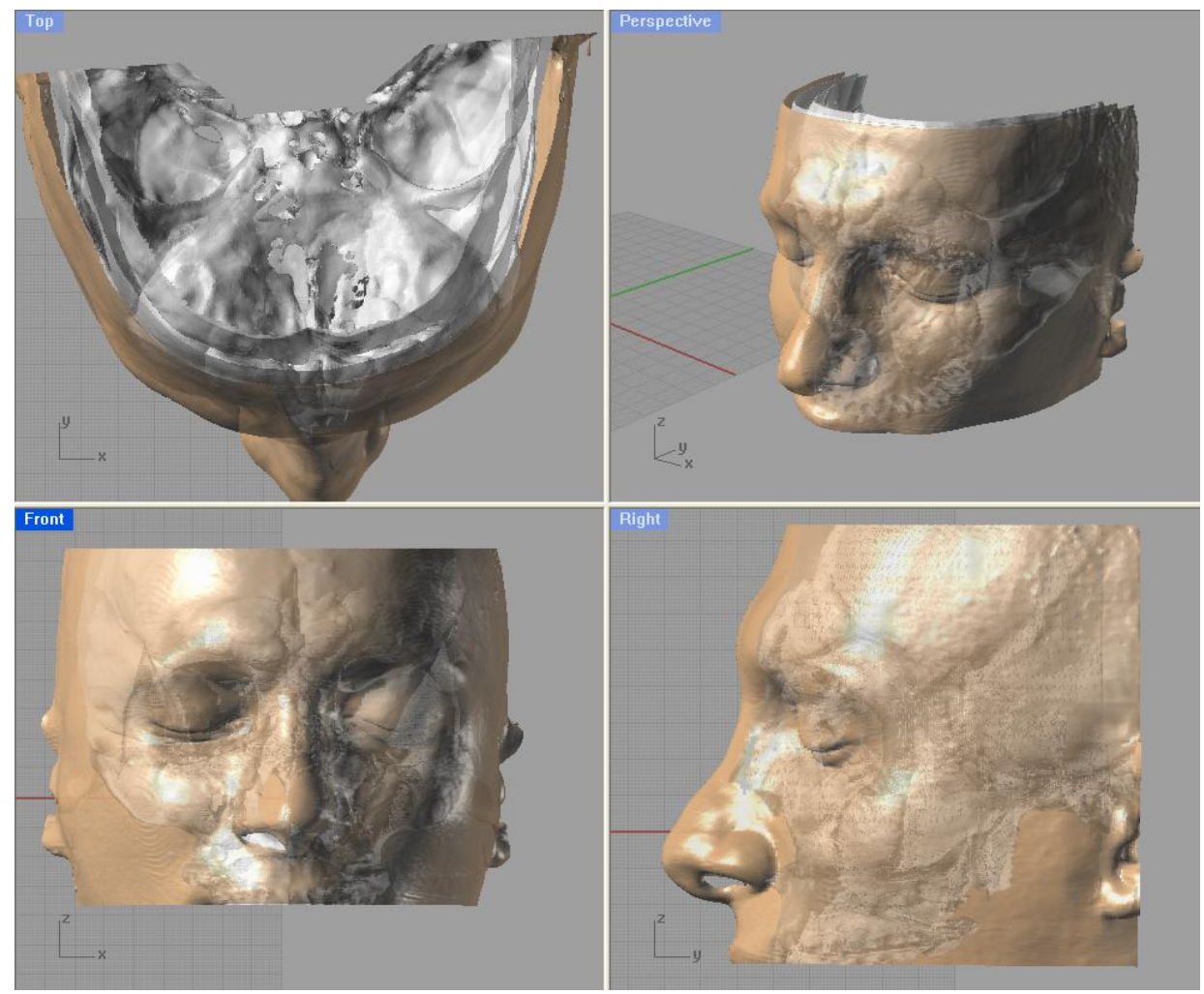

Figura 4. 3 - Esquema do modelo de crânio e face utilizado, doado pelo CTI Renato Archer

Apesar do modelo mostrado na figura 4.3 ser bastante detalhado, ele não pode ser utilizado diretamente para análise de elementos finitos, principalmente por conter uma quantidade demasiadamente grande de detalhes, o que torna sua representação pesada demais. Por isso e também por uma questão de otimização do uso de recursos, foi realizada uma remodelagem aplicando o protocolo de Biological Computer-Aided Design (BioCAD) desenvolvido no CTI.

O protocolo de BioCAD tem por objetivo possibilitar a descrição simplificada de estruturas anatômicas, mantendo as principais características de acordo com a aplicação que se deseja fazer do modelo. Portanto, viabiliza a representação apropriada de um conjunto predefinido de marcos anatômicos considerados importantes para o objetivo do modelo 3D, utilizando ferramentas geométricas 
disponíveis nas ferramentas Computer-Aided Design (CAD) de engenharia e uma abordagem representativa.

Esse protocolo foi aplicado ao modelo STL vindo do software InVesalius utilizando as ferramentas de modelagem 3D do programa Rhinoceros 4.0. Isso permitiu localizar linhas próximas a marcos anatômicos importantes e em locais determinados para favorecer, por exemplo, a localização do protetor nasal sobre a face do modelo.

A modelagem 3D pelo Rhinoceros foi feita utilizando o conceito de NonUniform Rational B-Splines (NURBS), segundo o qual superfícies de alta complexidade podem ser definidas por meio de linhas que sejam dispostas em suas extremidades e em seu interior, como linhas de controle. Estas superfícies foram dispostas de modo a representar a geometria 3D da anatomia retratada no arquivo STL, providenciando a simplificação necessária e controle, dado as superfícies foram divididas de acordo com as regiões anatômicas de importância.

Após a modelagem da anatomia da face, tanto na porção óssea quanto em tecido mole, foi desenvolvido o modelo do protetor nasal, segundo a mesma abordagem, ou seja, copiar os marcos anatômicos de apoio do protetor e modelar sua geometria como se houvesse sido conformada sobre a face, simulando o processo real de confecção.

Tanto o modelo da anatomia do tecido duro quanto a do tecido mole apresentam regiões de contato que tiveram sua representação compatível, de modo que as superfícies fossem cópias umas das outras na interface de contato. Essa abordagem visou facilitar a geração de uma malha de elementos finitos bem controlada e pares de contato consistentes. 
Da mesma maneira, as interfaces de contato entre os protetores modelados e a anatomia da face em tecido mole receberam o mesmo cuidado.

Finalmente, os modelos montados foram exportados em formato Standard for the Exchange of Product Model Data (STP) para que pudessem ser importados na ferramenta de pré-processamento de elementos finitos e utilizados como base para a geração da análise.

\subsection{AVALIAÇÃO DO PROTETOR NASAL EM AEF}

Como dito no item 4.6, foi sobreposto o protetor nasal preconizado pela disciplina ODC 384 - - Prótese Buco Maxilo Facial do Departamento de Cirurgia, Prótese e Traumatologia Maxilo Faciais da FOUSP (P1). A tabela 4.2 e a figura 4.4 mostram sua geometria e limites.

Tabela 4. 2 - Limites do protetor nasal P1

P1

Superior: Porção superior do osso frontal

Inferior: Região anterior do apêndice nasal

Lateral: Porção média do ossos zigomáticos 


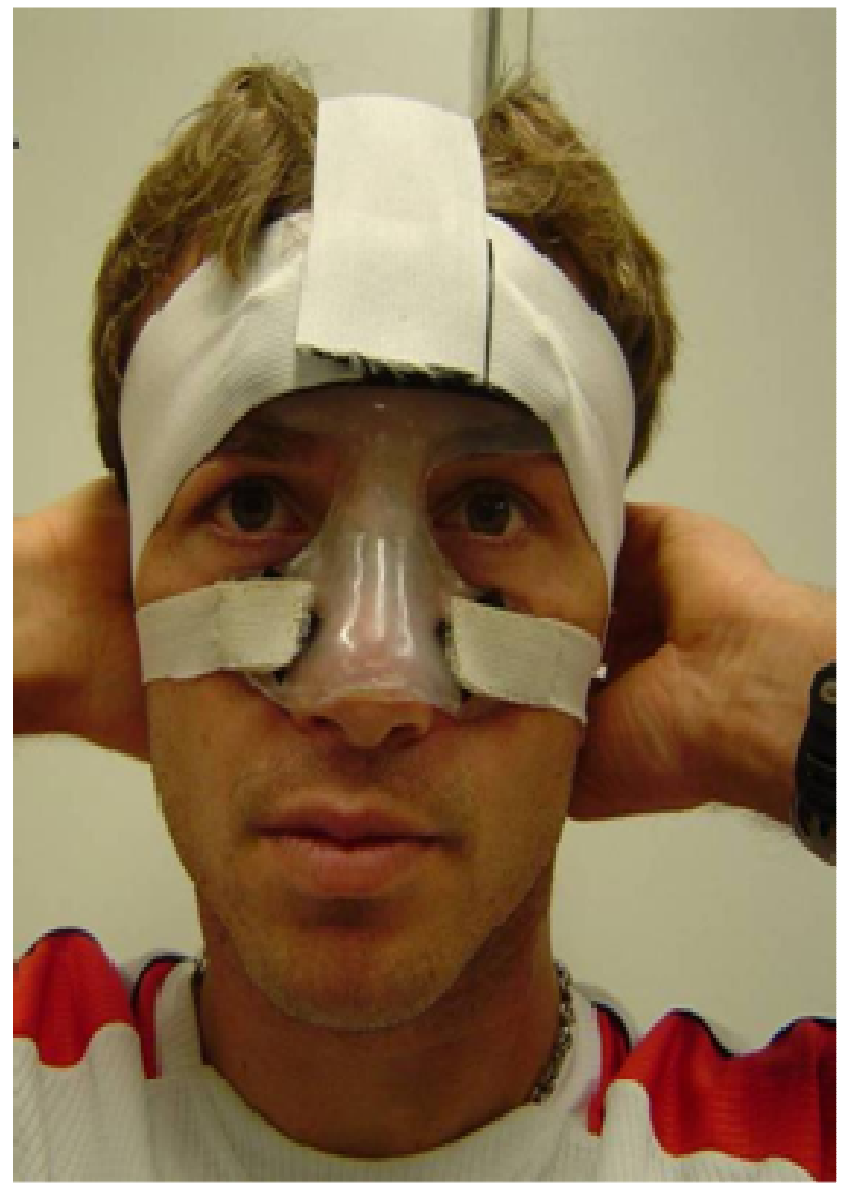

Figura 4.4 - Jogador de futebol com protetor com formato P1 


\section{RESULTADOS}

\subsection{DETERMINAÇÃO DAS CONSTANTES DE OGDEN DO EVA FLEXÍVEL}

O EVA flexível diferencia-se por apresentar alta elasticidade e baixa resistência mecânica. O seu comportamento elástico é semelhante ao dos elastômeros.

Os dados experimentais foram obtidos através de trabalho de ensaios experimentais conduzidos na máquina Instron, modelo 3369 com capacidade de carga de 50 kilo Newtons (KN) (Figura 5.5A) disponível no Laboratório do Grupo de Mecânica dos Sólidos e Impacto em Estruturas (GMSIE-POLI).A taxa de deslocamento imposta para os pratos durante o experimento quasi-estático foi de 1,0 milímetro por minuto( $\mathrm{mm} / \mathrm{min})$. A força e o deslocamento foram gravados.

Para o ensaio de compressão, foram utilizados discos de vinte $\mathrm{mm}$ de diâmetro e seis $\mathrm{mm}$ de altura, conforme mostra a figura 5.5B. Força e o deslocamento foram gravados por uma câmera de alta velocidade (Figura 5.6). 

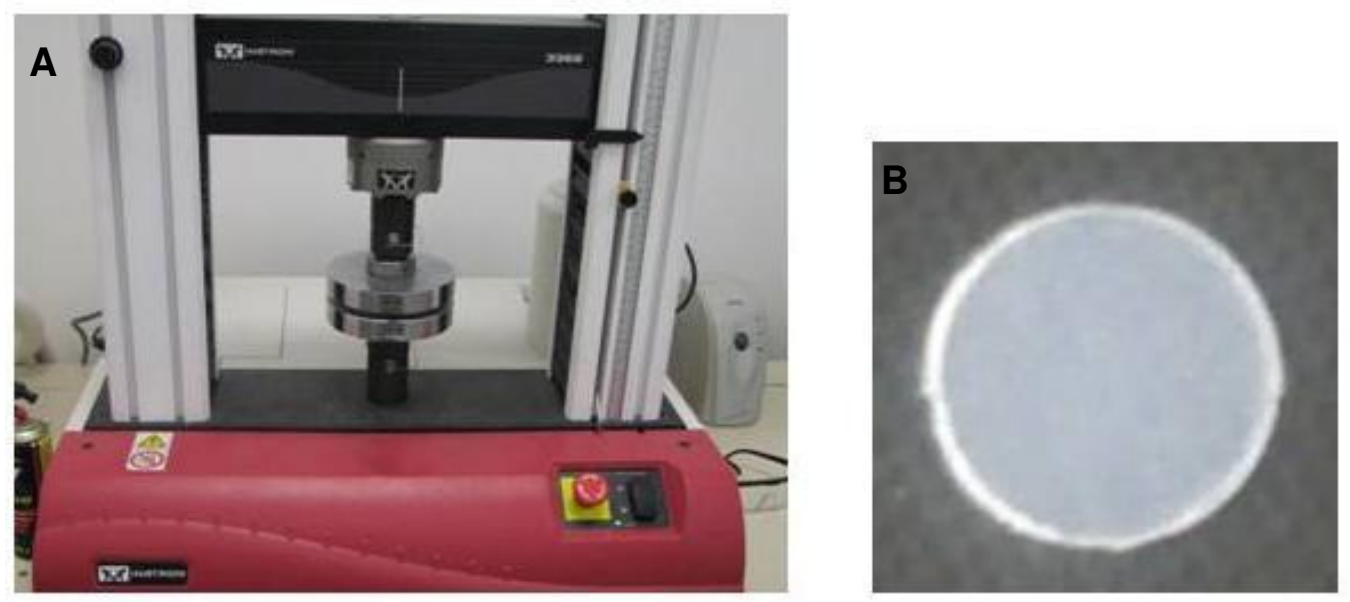

Figura 5.5 - A: Montagem do teste. .B: Detalhe da geometria do corpo de prova para teste de compressão
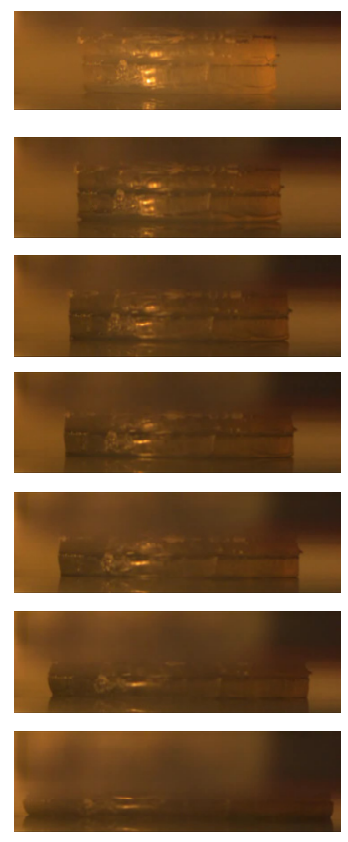

Figura 5.6 - Teste de compressão gravado por uma câmera de alta velocidade 


\subsubsection{Modelagem do problema}

A curva carga x deslocamento para o teste de compressão está apresentada na figura 5.7, nota-se a alta capacidade do EVA em suportar cargas de compressão, sendo a curva em formato exponencial da carga em função do deslocamento. Esta é uma informação importante, uma vez que durante o impacto em um protetor facial, a compressão é o esforço de maior importância (48).

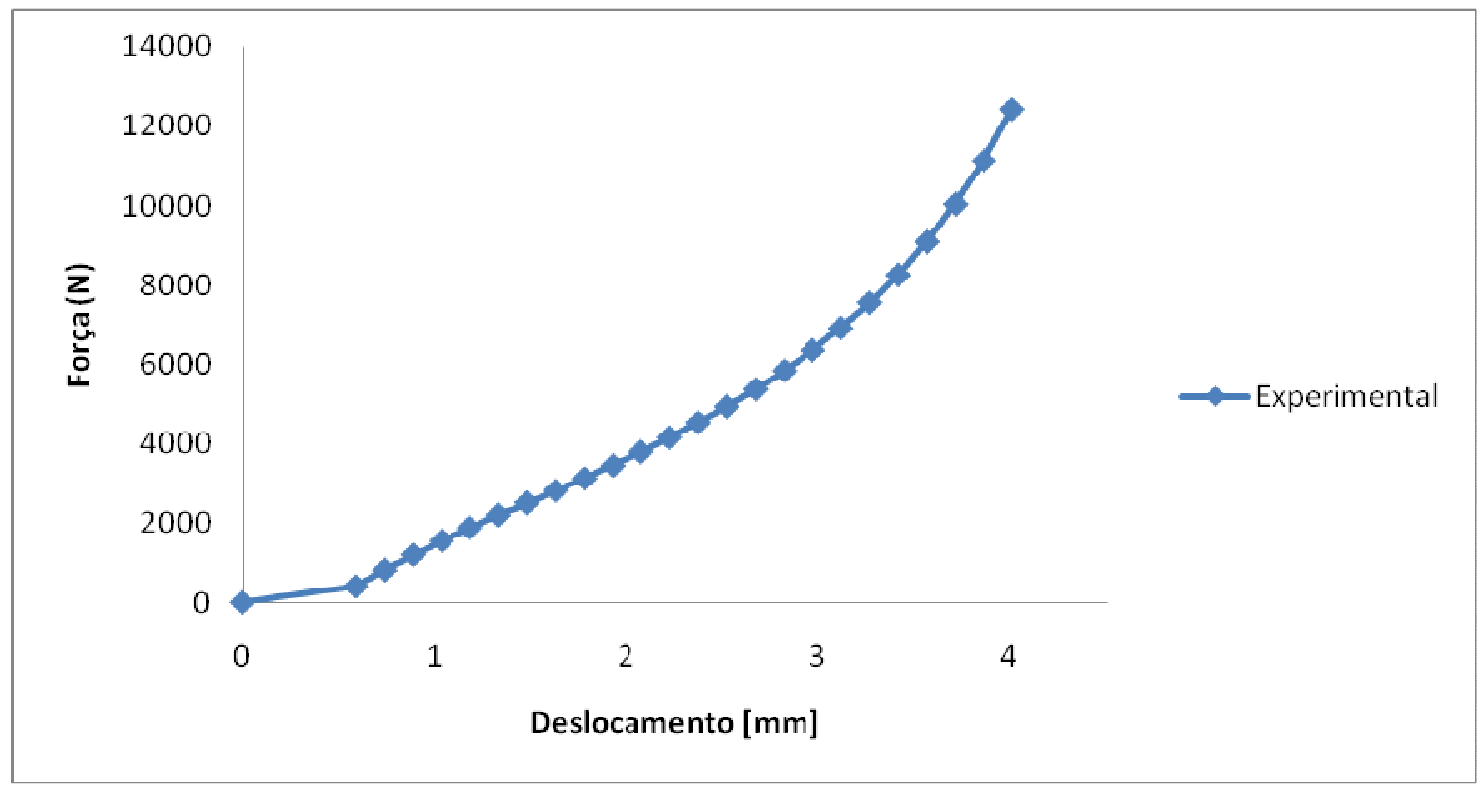

Figura 5. 7- Curva experimental para teste de compressão

Os pares de valores das constantes de Ogden para compressão estão apresentados na tabela 5.3. 
Tabela 5. 3 - Valores das constantes de Ogden

\begin{tabular}{c|c}
\hline \hline & Compressão \\
\hline$\mu_{1}$ & $\mathbf{7 , 0 0}$ \\
\hline$\mu_{2}$ & $\mathbf{2 , 6 0}$ \\
\hline$\alpha_{1}$ & $\mathbf{0 , 8 0}$ \\
\hline$\alpha_{2}$ & $\mathbf{2 , 6 0}$ \\
\hline \hline
\end{tabular}

O resultado obtido para os testes de compressão foi satisfatório. Portanto, podese considerar o material bem caracterizado.

\subsubsection{Construção dos modelos numéricos}

As simulações numéricas foram realizadas pelo programa LS Dyna (como descrito no item 4.2). Foi adotado o modelo Ogden Mat-77b.

Para cada um dos ensaios foi utilizado o EVA flexível, simulado com o modelo hiperelástico de Ogden $(45,46)$.

Conforme sugerido pelo manual do programa LS-Dyna (44), o grau do polinômio escolhido foi igual a dois, e, portanto, fez-se necessário fornecer dois pares de $\mu$ e $\alpha$. Estes foram determinados por estimativas de otimização (uma opção disponível no próprio programa LS-Dyna) e estão apresentados na tabela 5.3. Além dos dados acima, foi necessário fornecer a densidade $\left(2 \times 10-10 \mathrm{t} / \mathrm{mm}^{3}\right)$, 0 coeficiente de Poisson $(0,48)$ e o módulo de cisalhamento (10 MPa) dados obtidos na literatura (45).

A figura 5.8 mostra o modelo numérico do ensaio de compressão, com 5700 elementos finitos sólidos. Neste ensaio, foram feitos dois planos infinitos, nas 
extremidades do cilindro. O plano inferior (base) prendeu o corpo de prova e o plano superior impôs compressão ao corpo de prova, assim como no ensaio experimental.

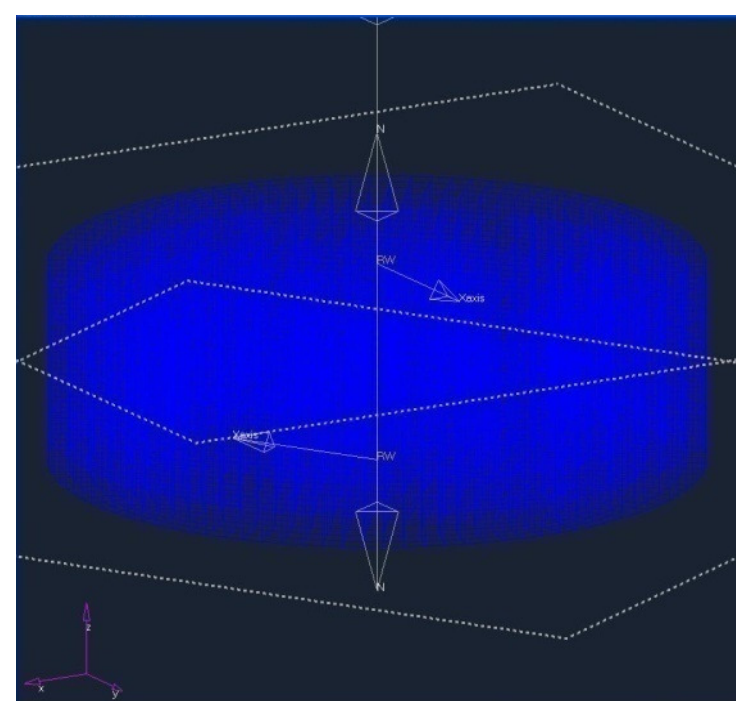

Figura 5. 8 - Modelo numérico do teste de compressão do EVA flexível

Para determinar a curva de tensão $x$ deformação, foi escolhido um ponto da extremidade superior na periferia do cilindro e as forças resultantes foram àquelas aplicadas na base.

As curvas força $x$ deslocamento do experimento mecânico e numérico foram ajustadas e coincidentes como mostra a figura 5.9. 

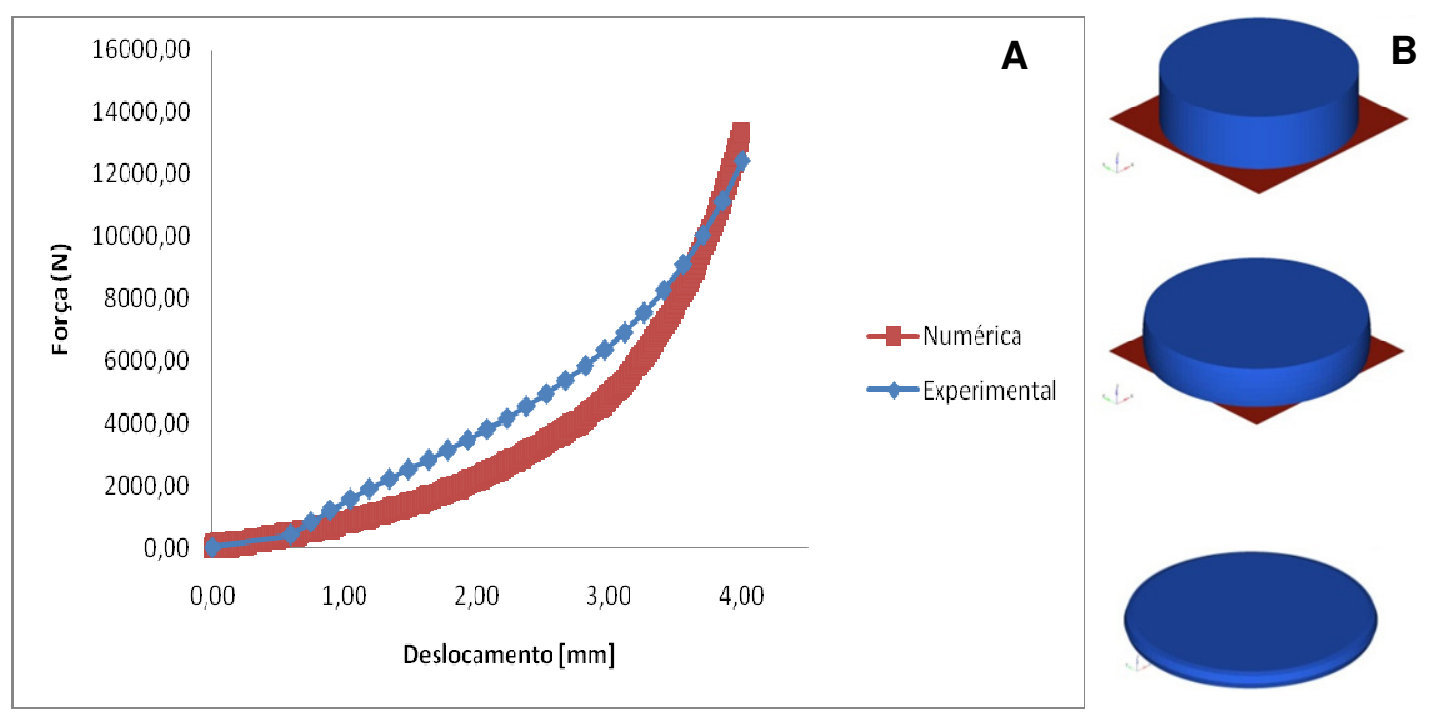

Figura 5. 9 - A: Curva experimental e numérica para teste de compressão. B: Evolução do ensaio de compressão numérica

A dificuldade em conseguir um ajuste dos parâmetros para os testes provavelmente se deve à alta anisotropia do EVA. A anisotropia do EVA pode ser justificada pelo deslocamento preferencial das macromoléculas constituintes na direção da deformação, gerando assim tensões residuais. Sendo essas direções de deformação diferentes na tração e na compressão, o EVA apresenta diferentes comportamentos nos diferentes tipos de ensaio. Vale ressaltar, novamente, que o comportamento do EVA está diretamente relacionado com fatores como seu peso molecular, sua cristalinidade, o grau de orientação e o teor de acetato de vinila.

A partir dos dados obtidos pode-se então montar a tabela 5.4 como modelo de material do EVA. 
Tabela 5. 4 - Modelo de material para o EVA: Parâmetros de Ogden e de Elasticidade

\begin{tabular}{c|c|c|c|c|c|c}
\hline \hline \multicolumn{4}{c|}{ Parâmetros de Ogden } & \multicolumn{3}{c}{ Parâmetros Elásticos } \\
\hline $\boldsymbol{\mu}_{\mathbf{1}}$ & $\boldsymbol{\mu}_{\mathbf{2}}$ & $\boldsymbol{\alpha}_{\mathbf{1}}$ & $\boldsymbol{\alpha}_{\mathbf{2}}$ & $\mathbf{G}(\mathbf{M P a})$ & $\boldsymbol{\rho}\left(\mathbf{t} / \mathbf{m m}^{\mathbf{3}}\right)$ & $\boldsymbol{v}$ \\
\hline 7,00 & 2,60 & 0,80 & 2,60 & 10 & $2,00 \mathrm{E}-09$ & 0,48 \\
\hline \hline
\end{tabular}

Com o intuito de calibrar o programa de finitos decidiu-se usar uma geometria complexa para se preparar para a geometria real a ser trabalhada obtida através de tomografia computadorizada. Foi utilizado então o protetor nasal preconizado pela Disciplina de Prótese Buco Maxilo Facial da FOUSP. O protetor nasal mostrado na figura 5.10, digitalizado através do uso de um scanner tridimensional. Este procedimento é de alta precisão, gerando uma malha muito densa e pesada, como pode ser visto na figura 5.11A. O software Hypermesh foi utilizado para o remodelamento da superfície mostrada na figura 5.11B, composta por 111.990 elementos de casca. O tamanho mínimo dos elementos da malha (comprimento, largura e espessura) foi especificado como dois $\mathrm{mm}$ de modo a resultar em um incremento de tempo razoável, uma vez que a análise foi explícita. 


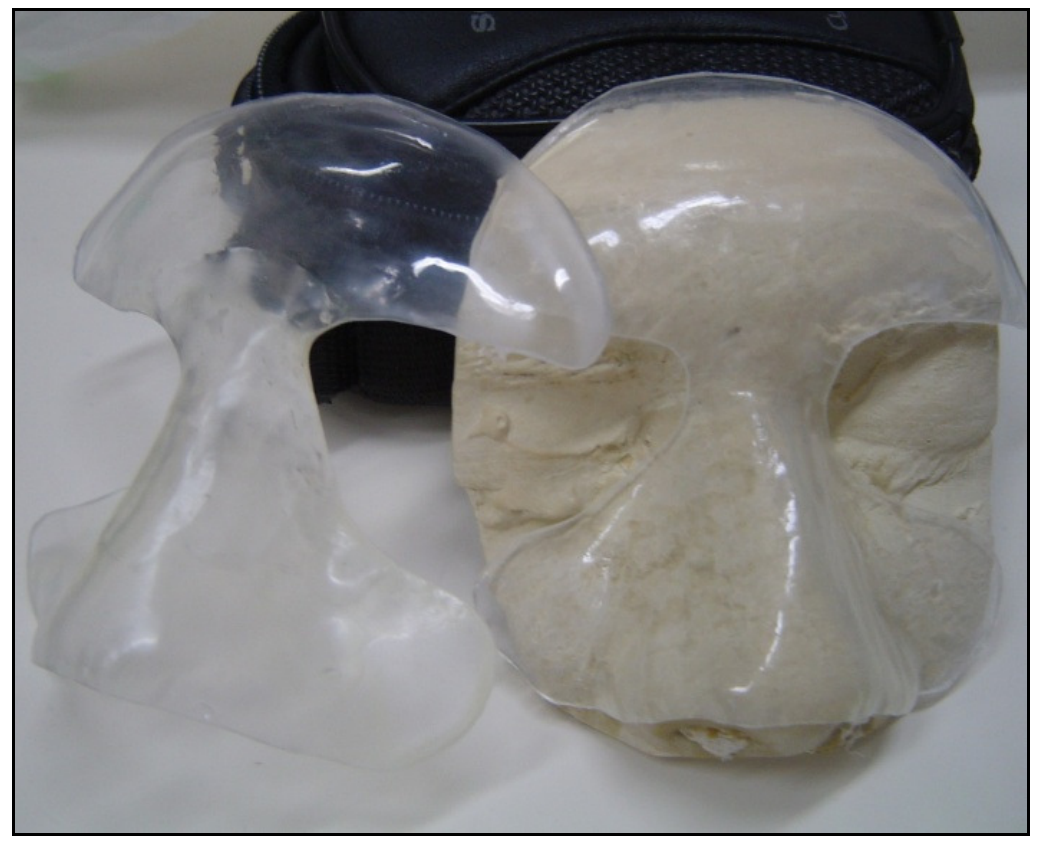

Figura 5.10 - Protetor P1 preconizado pela Disciplina de Prótese Buco Maxilo Facial da FOUSP

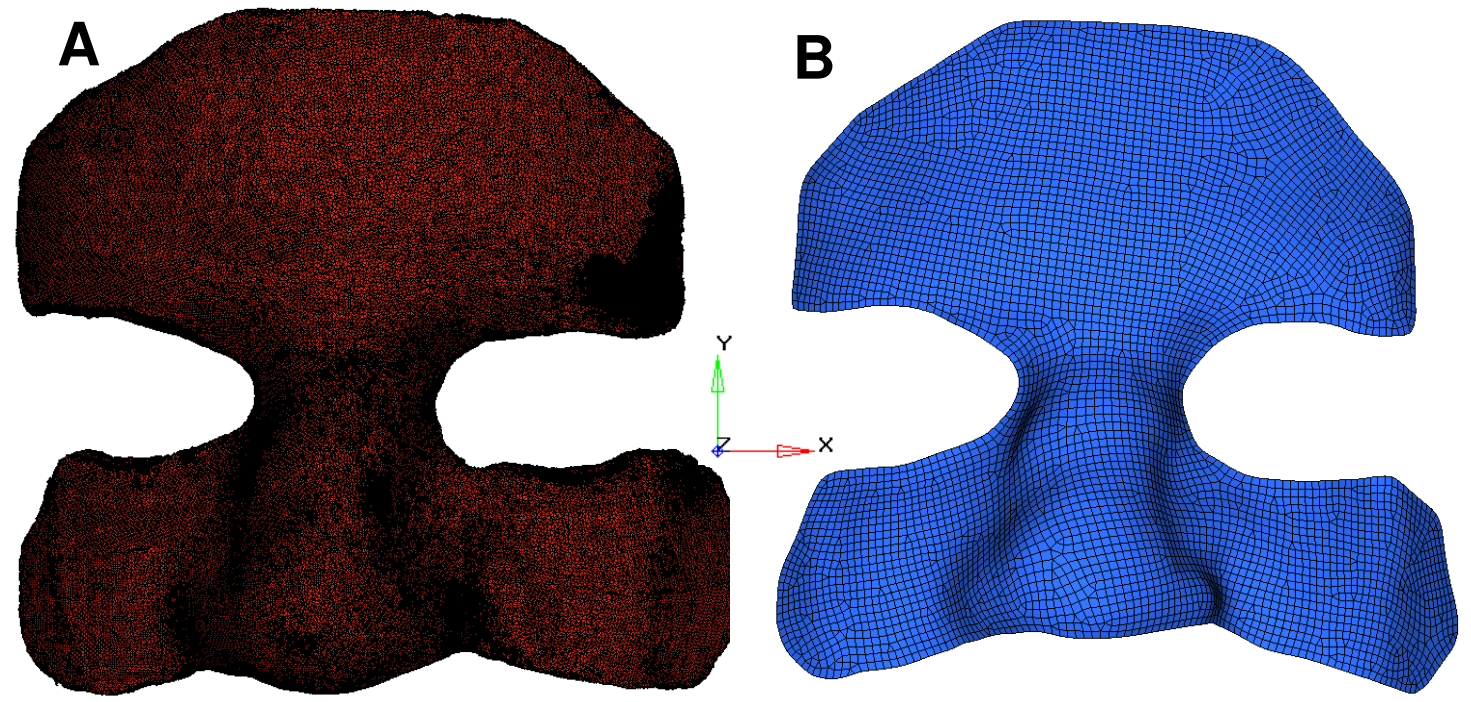

Figura 5. 11 - A: Imagem digitalizada do protetor nasal. B: Modelo da malha do protetor nasal

Com os parâmetros do osso obtidos através da literatura (descrito no item 4.4) pode-se montar a tabela $5.5(34,62)$, que apresenta os modelos de materiais para o osso, o qual foi modelado como elástico-linear, com critério de falha de máxima tensão principal. 
Tabela 5. 5 - Modelo de material para o osso: parâmetros elásticos e critério de falha

\begin{tabular}{c|c|c|c}
\hline \hline \multicolumn{2}{c|}{ Parâmetros Elásticos } & Critério de Falha \\
\hline $\boldsymbol{\rho}\left(\mathbf{t} / \mathbf{m m}^{\mathbf{3}}\right)$ & $\mathbf{E}(\mathbf{M P a})$ & $\mathbf{v}$ & Tensão Máxima Principal (MPa) \\
\hline $7,85 \mathrm{E}-04$ & $1.300,00$ & 0,30 & $0,13-0,34$ \\
\hline \hline
\end{tabular}

Para os tecidos moles (descrito no item 4.5) e de acordo com a literatura, uma lei linear não representa propriamente o comportamento mecânico de tecidos humanos, enquanto um modelo hiperelástico aparenta ser bastante coerente. Dentre os vários tipos de funções energia de deformação que conseguem descrever esta determinada resposta mecânica, vide, por exemplo, Bonet e Wood (62), o modelo adotado foi o modelo de Ogden $(58,59)$, e a tabela 5.6 resume seus parâmetros. As medidas de espessura dos ossos e do tecido mole foram estimadas através de tomografia computadorizada. Foram usadas as menores medidas, e valem $0,7 \mathrm{~mm}$ e $0,2 \mathrm{~mm}$, respectivamente.

Tabela 5. 6 - Modelo de material para o tecido mole: Parâmetros de Ogden e Parâmetros elásticos

\begin{tabular}{l|l|l|l|l|l|l|l}
\hline \multicolumn{4}{c}{ Parâmetros de Ogden } & \multicolumn{4}{c}{ Parâmetros elásticos } \\
\hline $\boldsymbol{\mu}_{\mathbf{2}}$ & $\boldsymbol{\mu}_{\mathbf{4}}$ & $\boldsymbol{\alpha}_{\mathbf{2}}$ & $\boldsymbol{\alpha}_{\mathbf{4}}$ & $\mathbf{G}(\mathbf{M P a})$ & $\boldsymbol{\rho}\left(\mathbf{t} / \mathbf{m m}^{\mathbf{3}}\right)$ & $\mathbf{v}$ \\
\hline 0,0059 & 0,0236 & 2,00 & 4,00 & 0,69 & $9,5 \mathrm{E}-10$ & 0,30 \\
\hline \hline
\end{tabular}




\subsection{MODELO DE PROTETOR NASAL PILOTO}

A figura 5.12 ilustra as três diferentes camadas do modelo - osso, tecido mole e protetor. Em cada camada a malha possui 111.990 elementos. Os nós nas extremidades periféricas da camada do osso têm um deslocamento restrito em todas as direções. A face fixa, como aqui modelada, é a situação mais crítica para o protetor. Em uma situação prática, se a cabeça estiver livre, o pescoço força a cabeça para trás durante o impacto, no entanto, isto diminuirá a força de impacto. Além disso, o tempo de impacto é muito pequeno, resultando então num pequeno deslocamento da cabeça como um todo. Contudo, o objetivo do protetor é proteger em todas as situações, como impactos em paredes rígidas ou contra o chão.

O contato aplicado entre as superfícies foi o surface to surface e o coeficiente de atrito considerado foi de 0,1 . Coeficientes de atrito mais baixos resultariam em condições mais críticas, uma vez que o protetor escorregaria sobre a pele. $\mathrm{O}$ valor do coeficiente de atrito está compatível com parâmetros encontrado na literatura (63). Na figura 5.12 o projétil é representado por uma esfera rígida composta por 324 elementos de casca, com um diâmetro de $30 \mathrm{~mm}$. A esfera possui uma massa de $0,05 \mathrm{Kg}$ e velocidade inicial de 20 metros/segundo $(\mathrm{m} / \mathrm{s})$.

Devido às grandes deformações ocorridas nos materiais modelados por Ogden, é necessário o uso do controle de Adaptative Lagrangian Eulerian (ALE). 


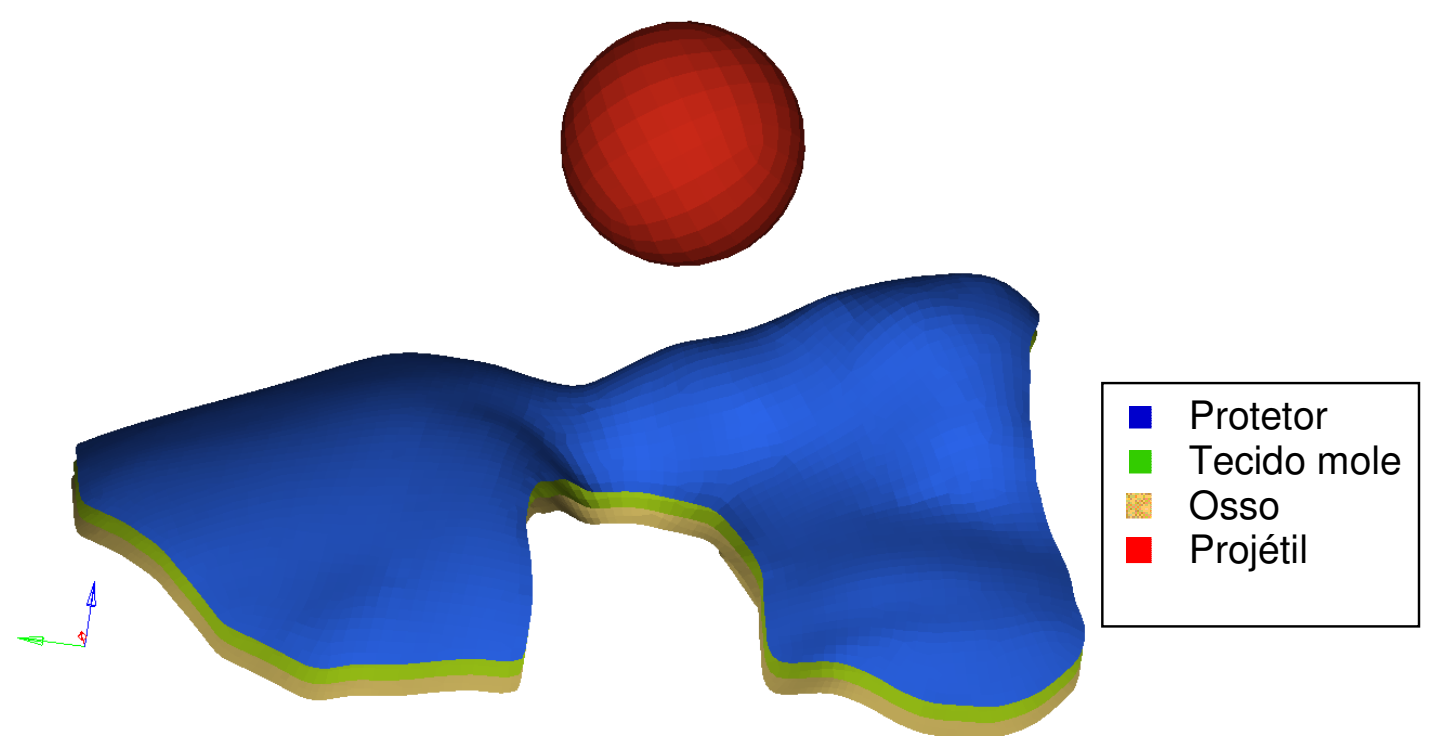

Figura 5. 12 - Modelo em elementos finitos do modelo piloto

\subsubsection{Resultados do modelo piloto}

A figura 5.13 mostra o perfil de pressão no protetor em diferentes instantes de análise do impacto da esfera. O impacto foi analisado por um tempo de $2 \mathrm{~ms}$. A pressão máxima obtida ocorreu na região do impacto e quando seu valor crítico foi atingido, houve a fratura do osso, como mostrado na figura 5.14. 

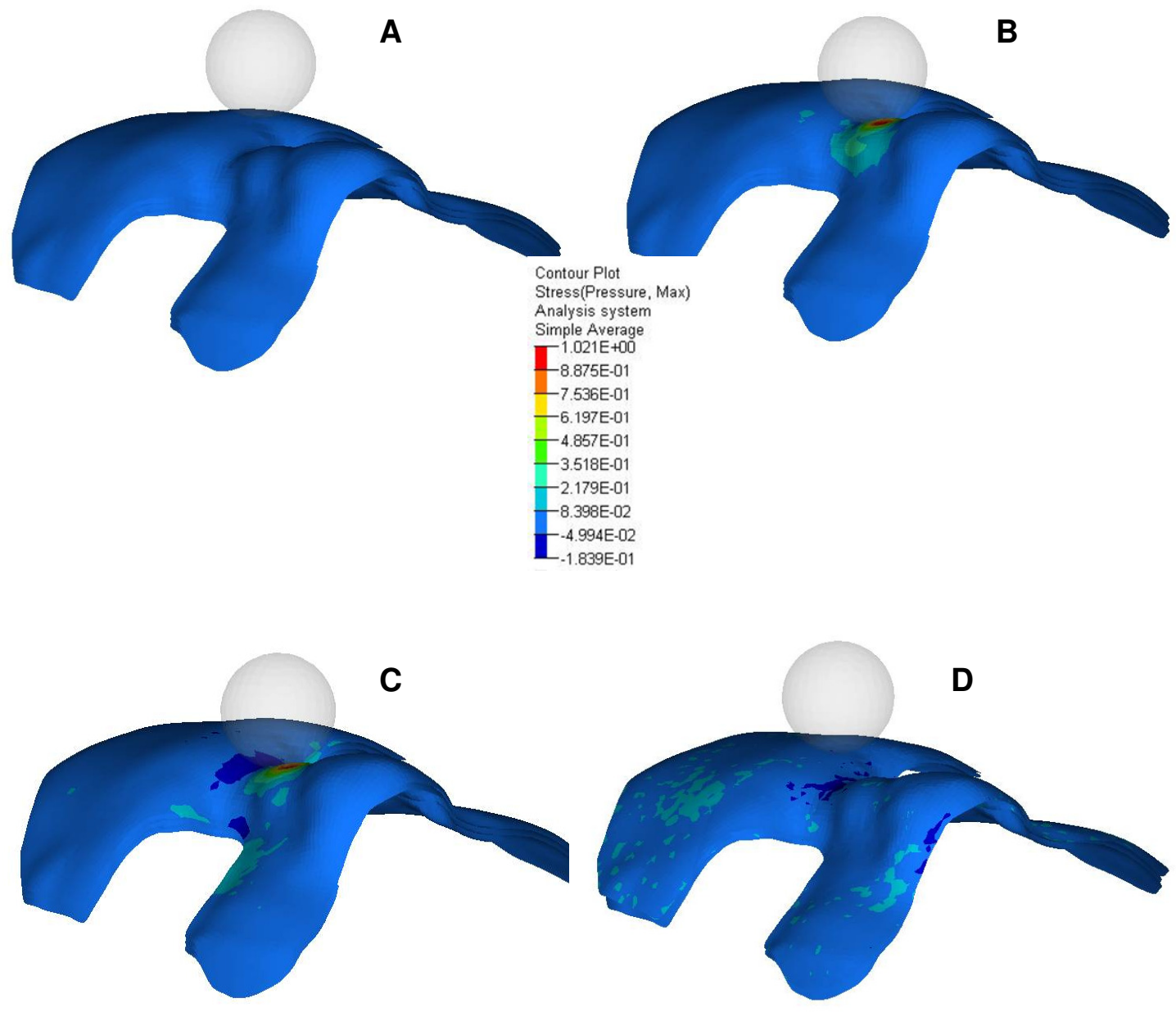

Figura 5. 13 - Perfil de pressão em diferentes instantes do impacto: A, B, C, D 

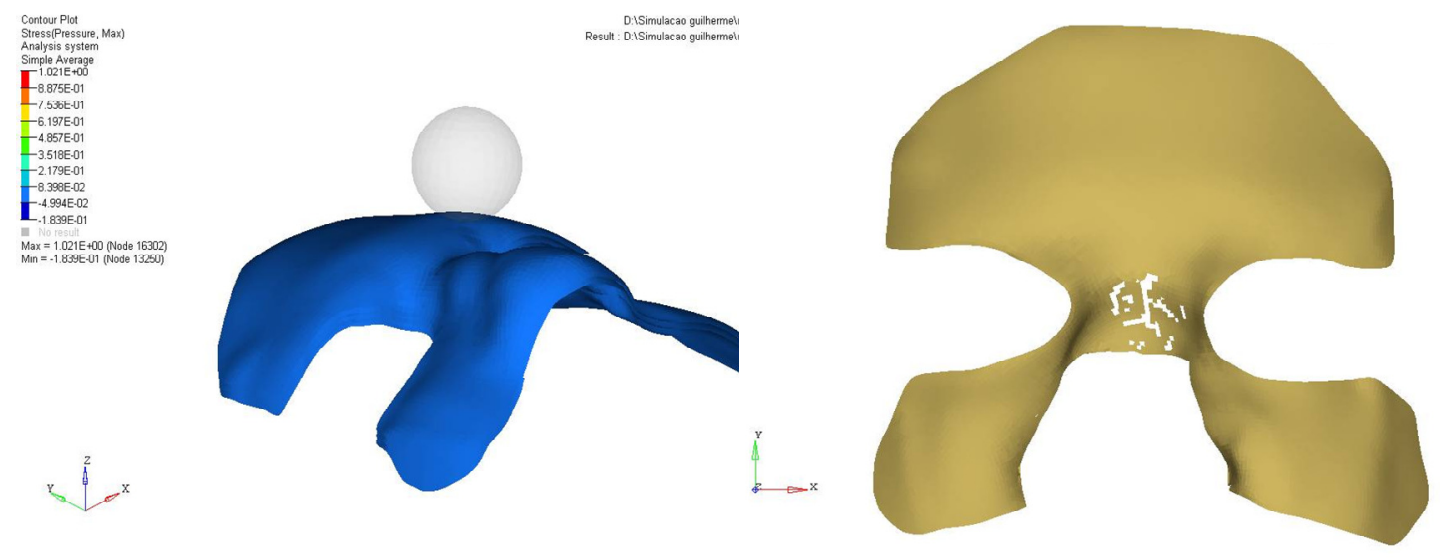

Figura 5. 14 - Falha do osso no modelo piloto

\subsection{DETERMINAÇÃO DAS CONSTANTES DE VON MISES PARA O EVA RÍGIDO}

Os dados experimentais foram obtidos através de ensaios experimentais conduzidos na máquina Instron, modelo 3369 com capacidade de carga de $50 \mathrm{KN}$ (Figura 5.5A) disponível no Laboratório do Grupo de Mecânica dos Sólidos e Impacto em Estruturas (GMSIE-POLI). A taxa de deslocamento imposta para os pratos durante o experimento quasi-estático foi de $1,0 \mathrm{~mm} / \mathrm{min}$. A força e 0 deslocamento foram gravados, assim como para o EVA flexível.

Para o ensaio de compressão, foram utilizados discos de dois $\mathrm{mm}$ de diâmetro e seis $\mathrm{mm}$ de altura, conforme mostra a figura 5.5B. Força e o deslocamento foram gravados por uma câmera de alta velocidade. 


\subsubsection{Modelagem do problema}

A curva carga $x$ deslocamento para o teste de compressão está apresentada na figura 5.15, sendo a curva em formato exponencial da carga em função do deslocamento.

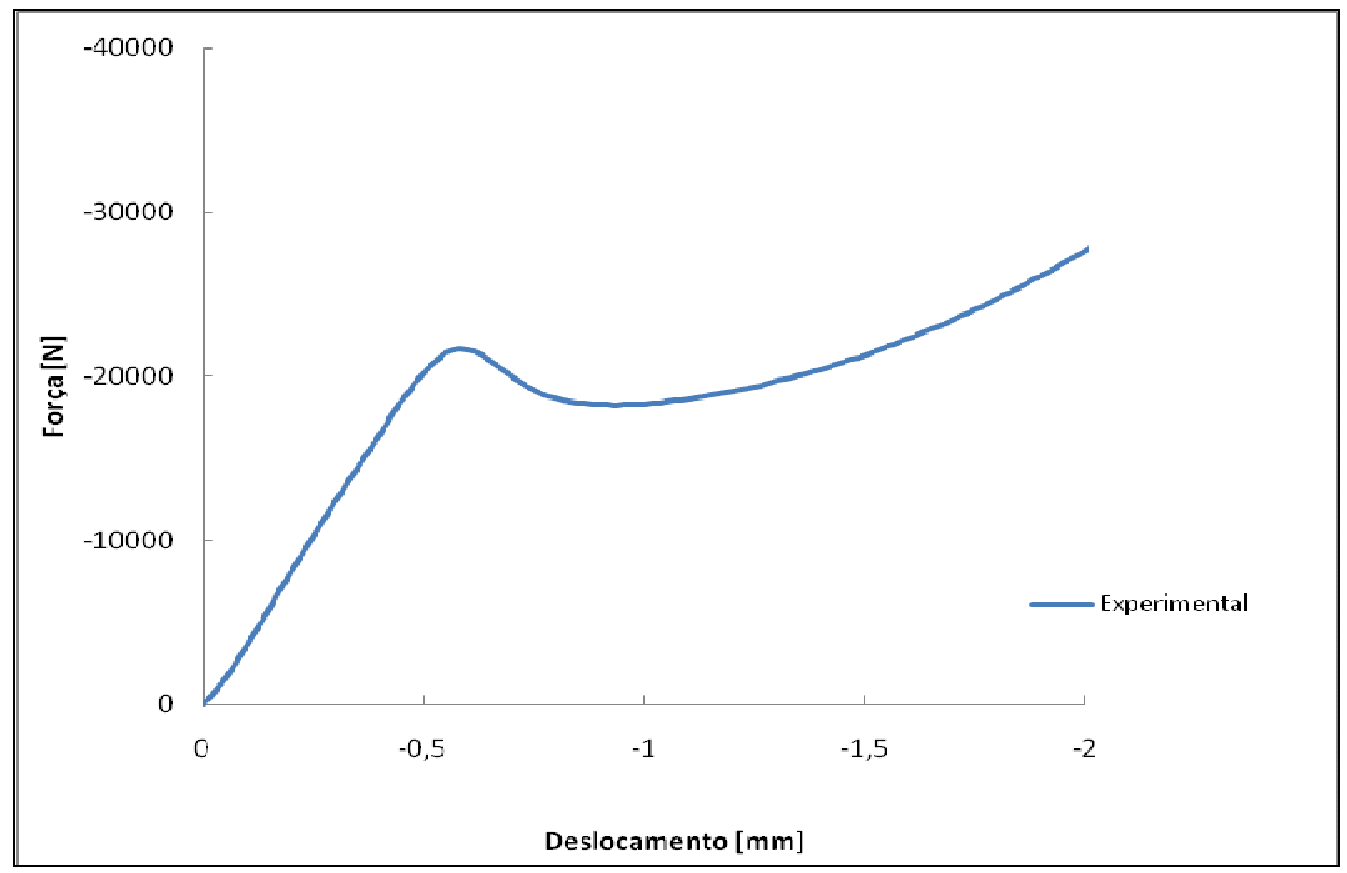

Figura 5. 15 - Curva experimental para teste de compressão 


\subsubsection{Construção dos modelos}

As simulações numéricas foram realizadas pelo programa LS Dyna (como descrito no item 4.2). Foi adotado o modelo elastoplástico de Von Mises bilinear.

Foi necessário fornecer a densidade $\left(9.4000 \mathrm{E}-10 \mathrm{t} / \mathrm{mm}^{3}\right)$, o coeficiente de Poisson $(0,48)$, módulo de elasticidade (480MPa), tensão de escoamento (46MPa), módulo tangente $(0,1 \mathrm{MPa})$ e deformação de ruptura $(1,2)$ dados obtidos através de ajustes da curva numérica com a experimental (Figura 5.17). A figura 5.16 mostra o modelo numérico do ensaio de compressão, com 1350 elementos finitos sólidos. Neste ensaio, foram feitos dois planos infinitos, nas extremidades do cilindro. $O$ plano inferior (base) prendeu o corpo de prova e o plano superior impôs compressão a ele, assim como no ensaio experimental.

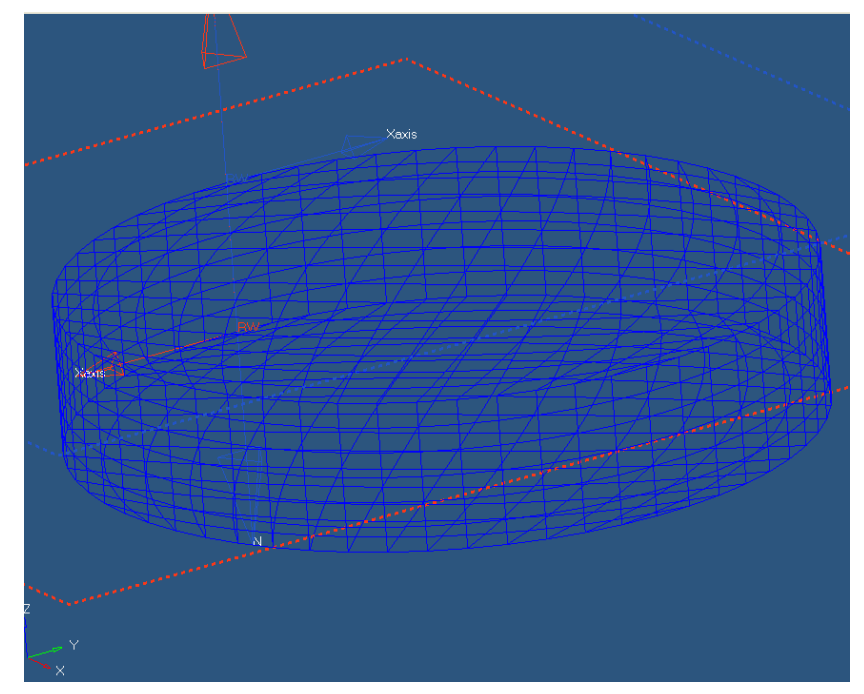

Figura 5.16 -- Modelo numérico do teste de compressão do EVA rígido

Para determinar a curva de tensão $\mathrm{x}$ deformação, foi escolhido um ponto da extremidade superior na periferia do cilindro e as forças resultantes foram àquelas 
aplicadas na base. As curvas força $x$ deslocamento do experimento mecânico e numérico foram ajustadas e coincidentes como mostra a figura 5.17.

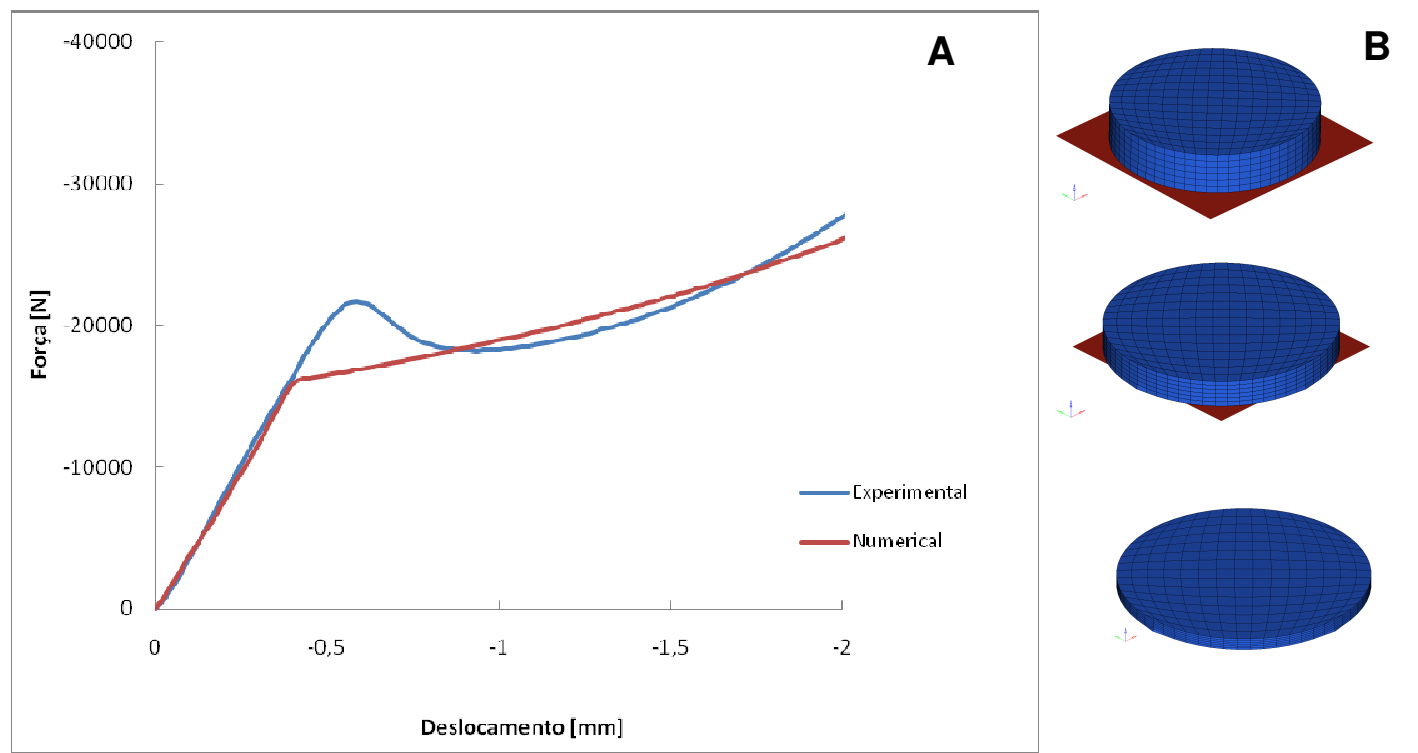

Figura 5. 17 - A: Curva experimental e numérica para teste de compressão. B: Evolução do ensaio

\subsection{MODELO FINAL DA GEOMETRIA COMPLETA}

A imagem da face utilizada neste estudo provém da digitalização de tomografia computadorizada, como descrito no item 4.6. Sua porção óssea mostra, em cores (Figura 5.18), os ossos que a compõem e suas respectivas resistências ao impacto (Tabela 4.1 descrita no item 4.4). Foi importante a diferenciação entre os ossos faciais devido à variação da resistência ao impacto que os mesmos apresentam. Cada osso representado tem espessura distinta, diferente do modelo piloto, e presente nesta apresentação.

O número de elementos do tecido ósseo foi de 201.995, e o número de nós foi de 48.691. 


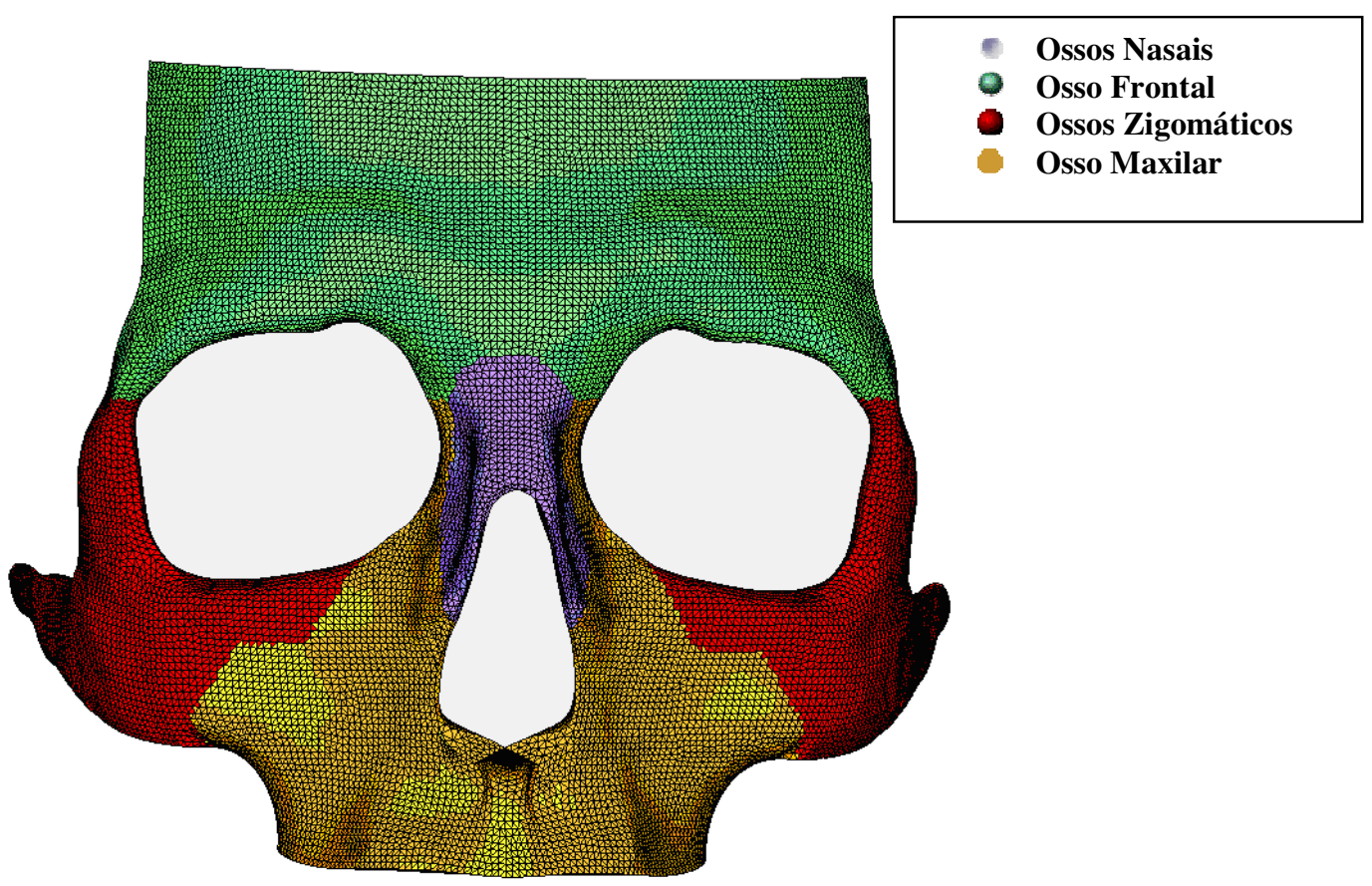

Figura 5. 18 - Porção óssea da face estudada

A imagem do tecido mole (Figura 5.19) tem suas características descritas no item 4.5. Número de elementos osso tecido mole foi de 160.537, e o número de nós foi de 36.507 .

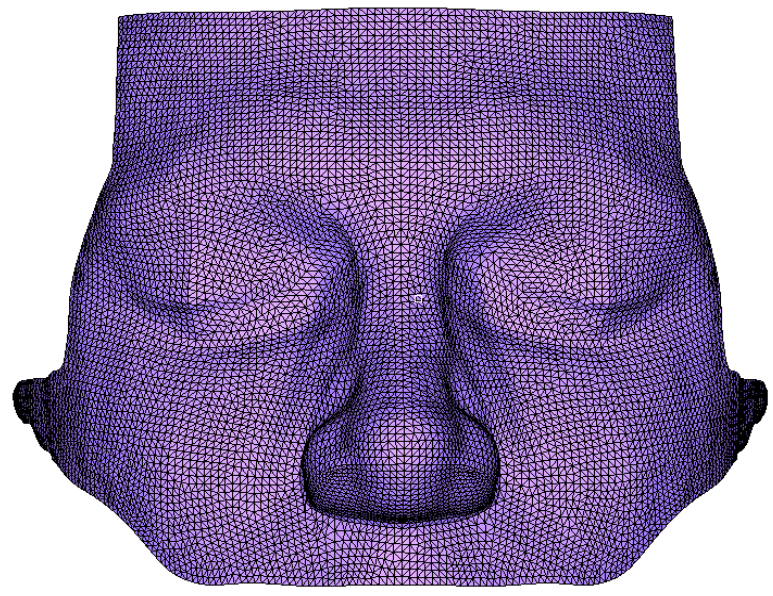

Figura 5.19 - Porção do tecido mole da face estudada

As imagens do osso e tecido mole foram sobrepostas (Figura 5.20). 


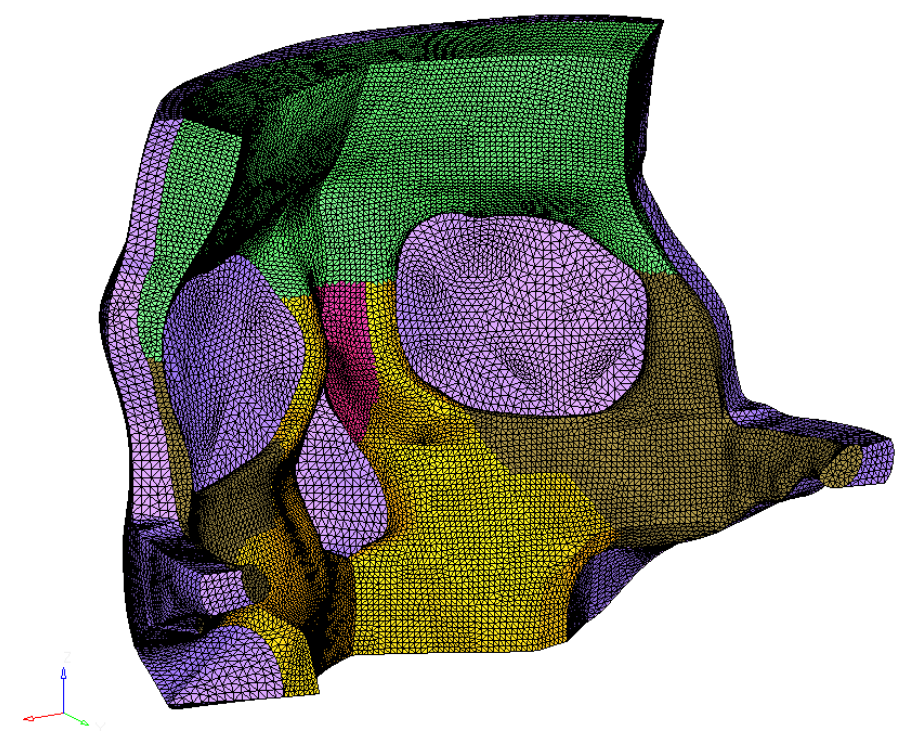

Figura 5.20 - Sobreposição das camadas osso e tecido mole da face

O conjunto osso e tecido mole recebeu a geometria, também por sobreposição, do protetor nasal estudado P1 e conforme recorte descrito no item 4.7 , tabela 4.2 e figura 4.4 .

O protetor nasal P1 (Figura 5.21) gerou 373.261 elementos e 96.247 nós. Os nós nas extremidades periféricas da camada do osso têm um deslocamento restrito em todas as direções. 


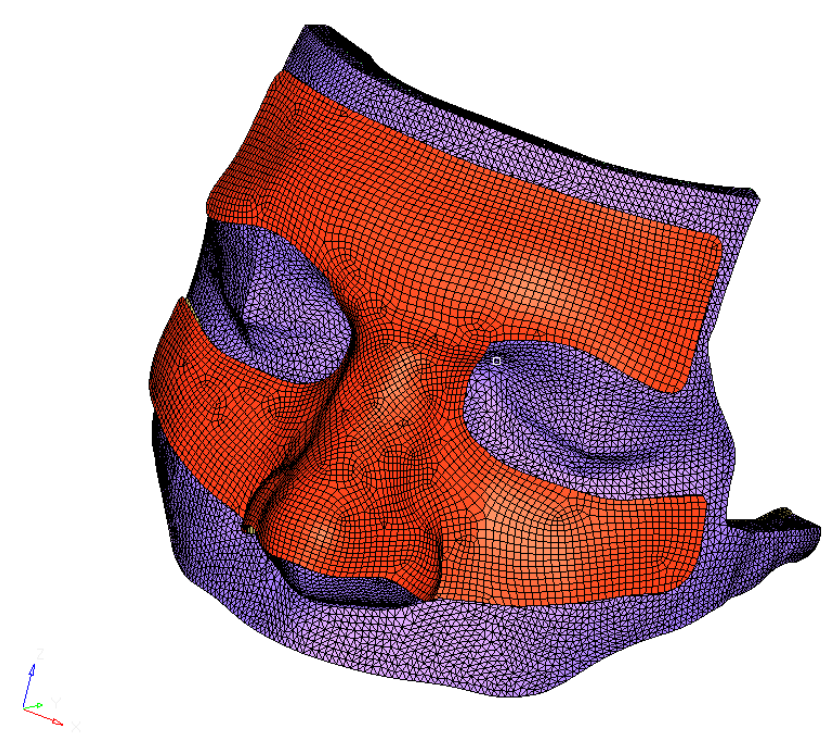

Figura 5.21 - Malha do protetor P1.

Para o estudo do protetor o osso e o tecido mole foram considerados elementos sólidos e o protetor P1 elemento de casca, sendo composto por uma lâmina de EVA flexível sobreposta por uma lâmina de EVA rígida

Como já dito, a face foi modelada como fixa, pois o tempo de impacto é muito pequeno para que o deslocamento da cabeça influencie na resposta $(29,30)$.

A cada parte: projétil, protetor, tecido mole e osso - foi ainda aplicado o modelo de contato indicado, disponível no software LS-Dyna (surface to surface entre projétil e protetor rígido, e nodes to surface entre protetores e protetor e tecido mole). Dessa forma, a deformação em uma parte interfere nas tensões e deformações das partes adjacentes. Particularmente, os nós do tecido mole e osso foram colados (tied nodes).

Na figura 5.22, o projétil, como no projeto piloto, é representado por uma esfera rígida composta por 324 elementos de casca, com um diâmetro de $30 \mathrm{~mm}$. A esfera possui uma massa de $0,025 \mathrm{~kg}$ e velocidade de $20 \mathrm{~m} / \mathrm{s}$. 


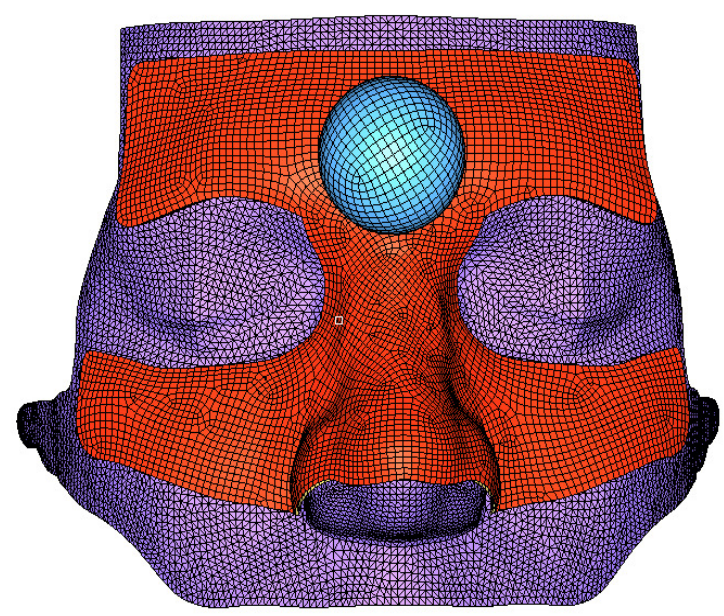

Figura 5. 22 - Modelo em elementos finitos completo: osso + tecido mole +do protetor P1

As restrições de contorno para o protetor P1 foram determinadas de acordo com a fixação pericraniana que os protetores nasais têm quando estão posicionados no atleta (região delimitada na cor branca, da Figura 5.23).

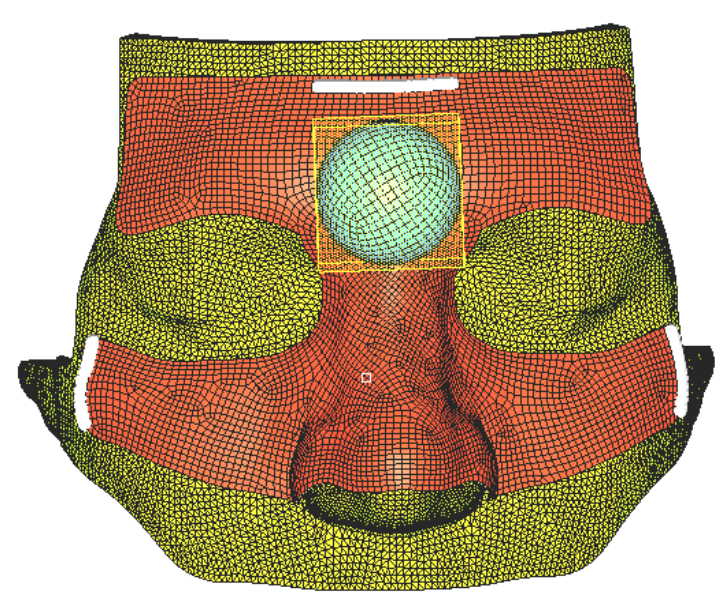

Figura 5. 23 - Restrições de contorno do protetor nasal P1 


\subsection{AVALIAÇÃO DO PROTETOR NASAL EM AEF}

Para a avaliação do protetor nasal em AEF foi simulado, nas mesmas condições, o modelo facial sem a presença do protetor (A) e o modelo facial com a presença do protetor P1 (B) como mostrado abaixo na figura 5.24 no instante inicial da análise.

Os resultados foram analisados em dois instantes: intermediário e crítico. $\mathrm{O}$ instante intermediário, em 5,7 microsegundos ( $\mu \mathrm{s}$ ) mostra o impacto do projétil (Figura 5.25) e instante crítico, em 9,1 $\mu \mathrm{s}$, mostra a fratura dos ossos nasais, no caso de impacto (Figura 5.26).

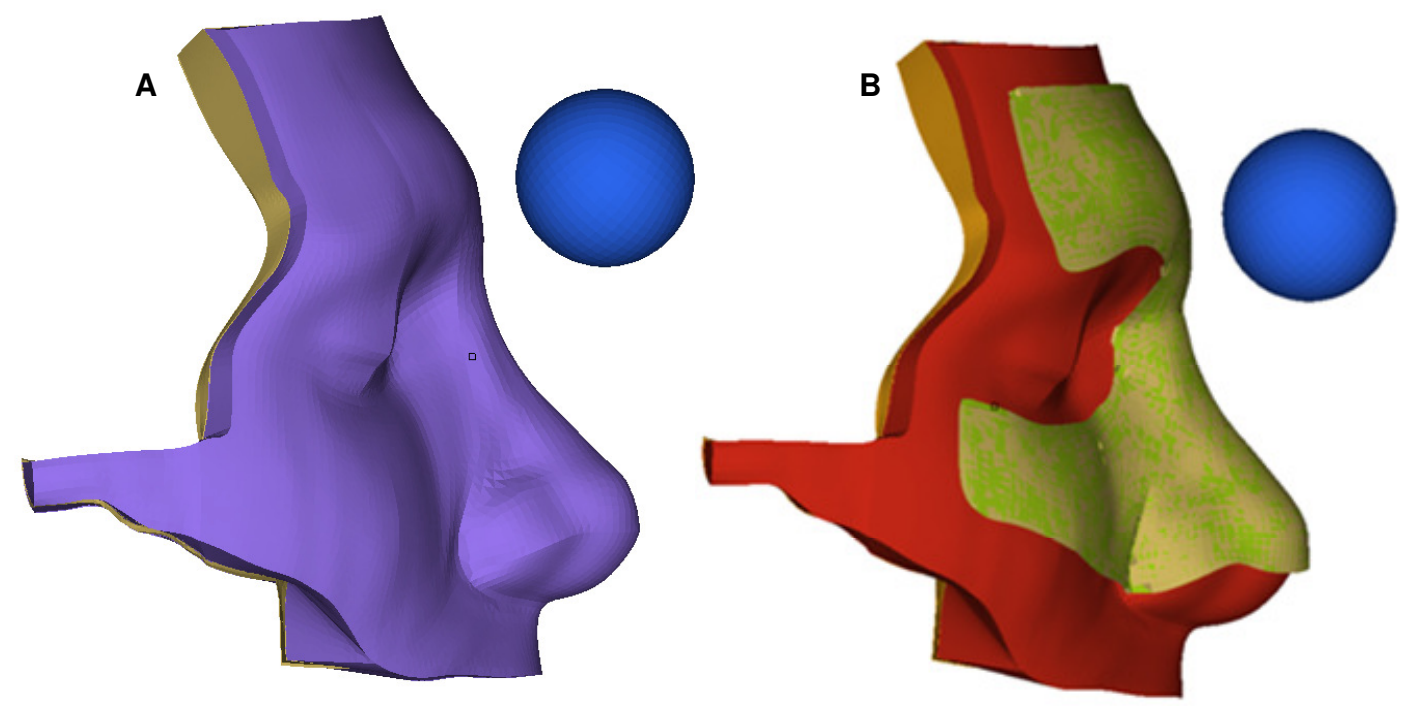

Figura 5.24 - Instante inicial da análise: A - modelo facial sem protetor nasal. B: modelo facial com protetor nasal P1 

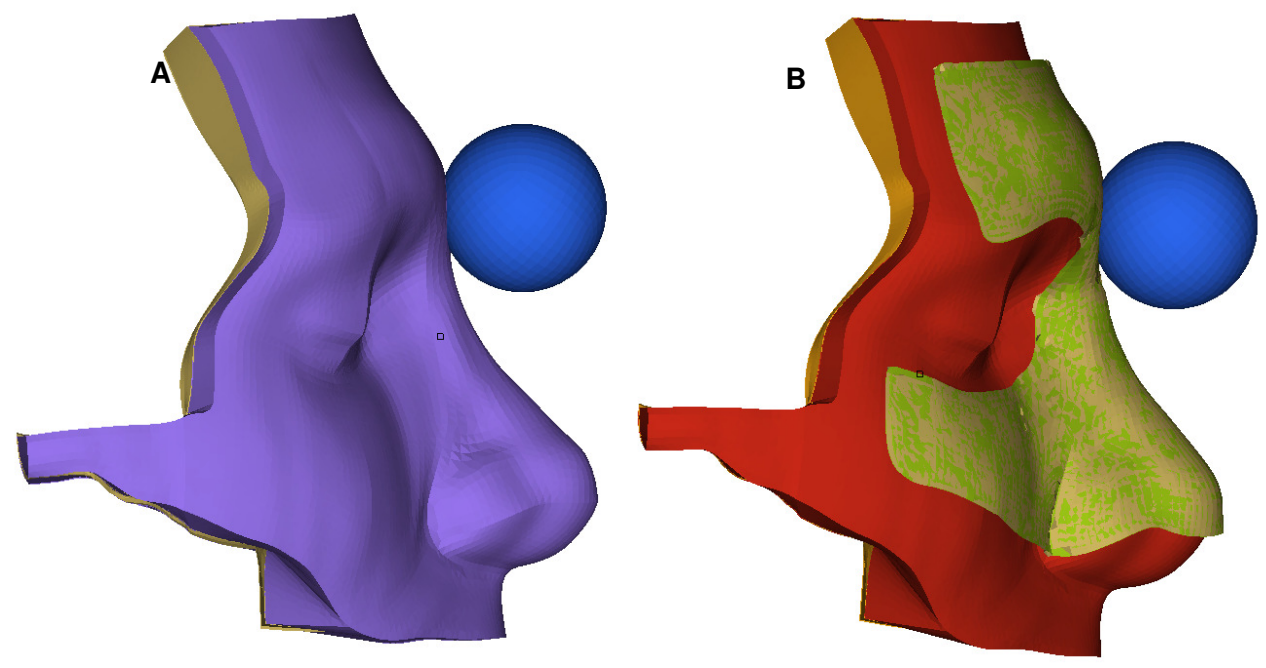

Figura 5.25 - Instante intermediário da análise: A - modelo facial sem protetor nasal. B: modelo facial com protetor nasal P1
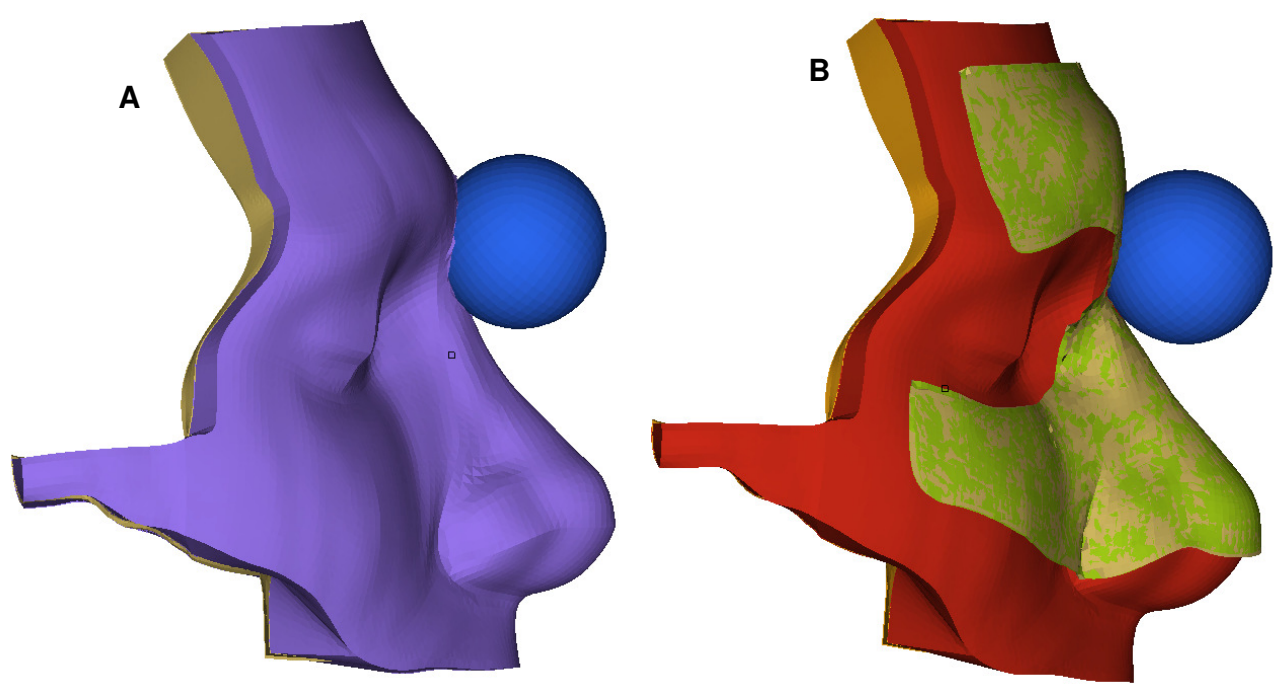

Figura 5.26 - Instante crítico da análise: A - modelo facial sem protetor nasal. B: modelo facial com protetor nasal P1

A figura 5.27 mostra o perfil de pressão (como estudado no item 5.2.1) na porção óssea sem a presença do protetor, no instante crítico da análise. A figura 5.28 mostra o perfil de pressão no modelo facial com a presença do protetor nasal P1. O impacto foi analisado por um tempo de $9,1(\mu \mathrm{s})$. No caso do modelo facial sem 
protetor, a pressão máxima obtida ocorreu na região do impacto e quando seu valor crítico foi atingido, 0,13 MPa, em que houve a fratura dos ossos nasais.

$$
\begin{array}{r}
-3.400 E-01 \\
-3.167 \mathrm{E}-01 \\
-2.933 \mathrm{E}-01 \\
-2.700 \mathrm{E}-01 \\
-2.467 \mathrm{E}-01 \\
-2.233 \mathrm{E}-01 \\
-2.000 \mathrm{E}-01 \\
-1.767 \mathrm{E}-01 \\
-1.533 \mathrm{E}-01 \\
-1.300 \mathrm{E}-01 \\
\text { No result }
\end{array}
$$

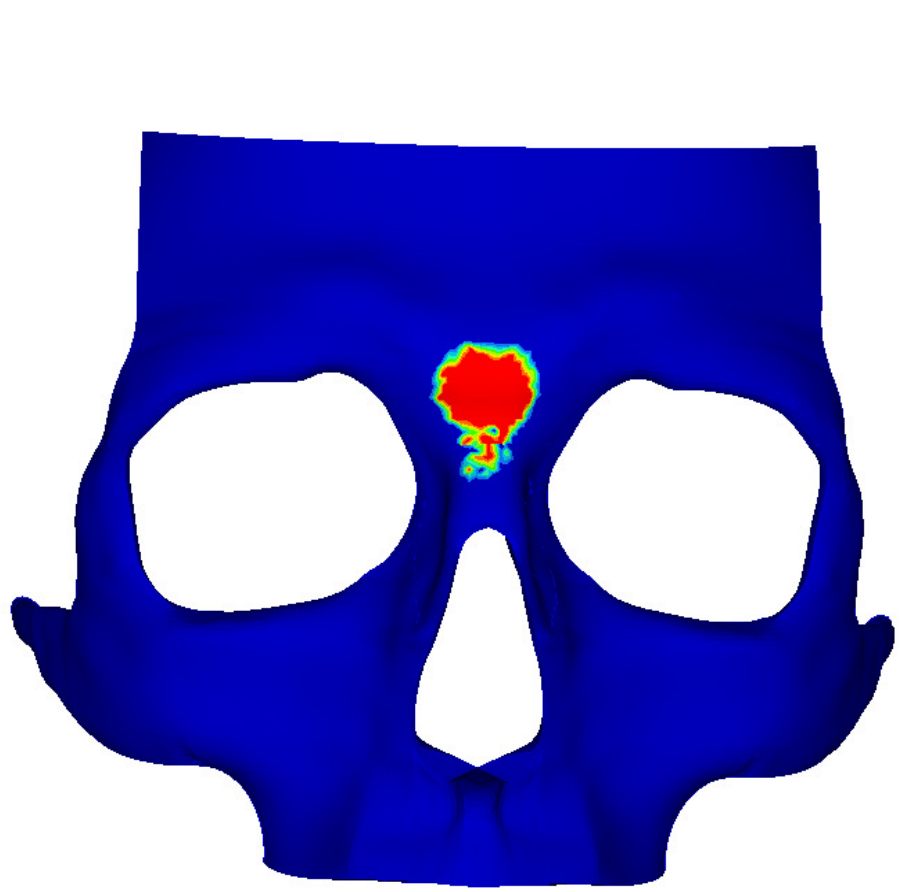

Figura 5.27 - Análise da porção óssea no instante crítico. Modelo facial sem protetor

$$
\begin{array}{r}
-3.400 \mathrm{E}-01 \\
-3.167 \mathrm{E}-01 \\
-2.933 \mathrm{E}-01 \\
-2.700 \mathrm{E}-01 \\
-2.467 \mathrm{E}-01 \\
-2.233 \mathrm{E}-01 \\
-2.000 \mathrm{E}-01 \\
-1.767 \mathrm{E}-01 \\
-1.533 \mathrm{E}-01 \\
-1.300 \mathrm{E}-01
\end{array}
$$
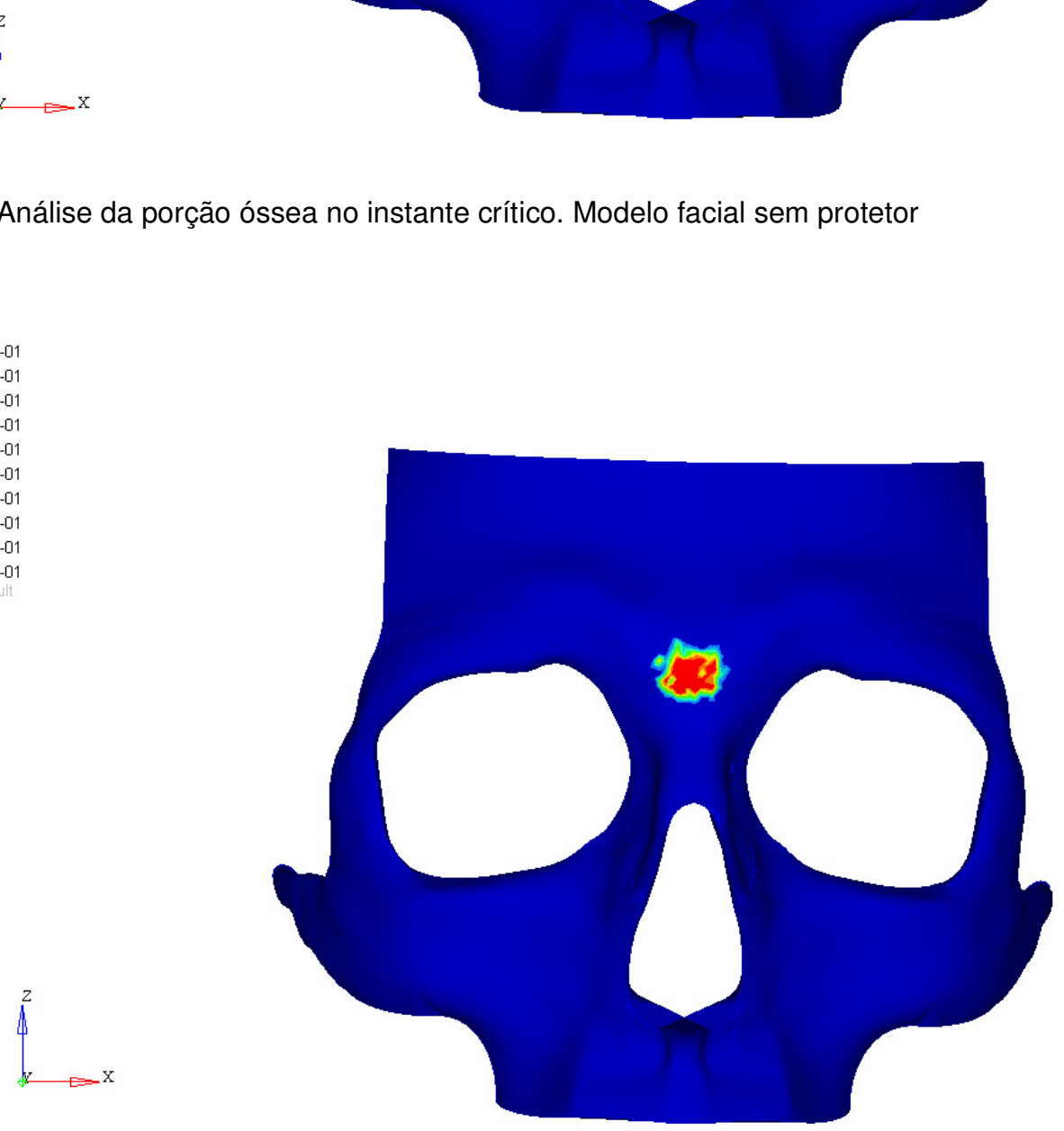

Figura 5. 28 - Análise da porção óssea no instante crítico. Modelo facial com protetor nasal P1 
A trajetória do projétil e a anatomia da face fazem com que o osso frontal seja também atingido. Para atestar que a falha ocorreu na região dos ossos nasais a figura 5.29 mostra a sobreposição da malha com as divisões ósseas como foram referidas na figura 5.18 , atestando que a falha sem protetor ocorreu na região dos ossos nasais. Figura similar, para o caso com protetor (Figura 5.30), mostra que não houve fratura do osso nasal. Convém ressaltar que a resistência do osso frontal é até 70 vezes maior $(\geq 7,58 \mathrm{MPa}-$ Tabela 4.1$)$.

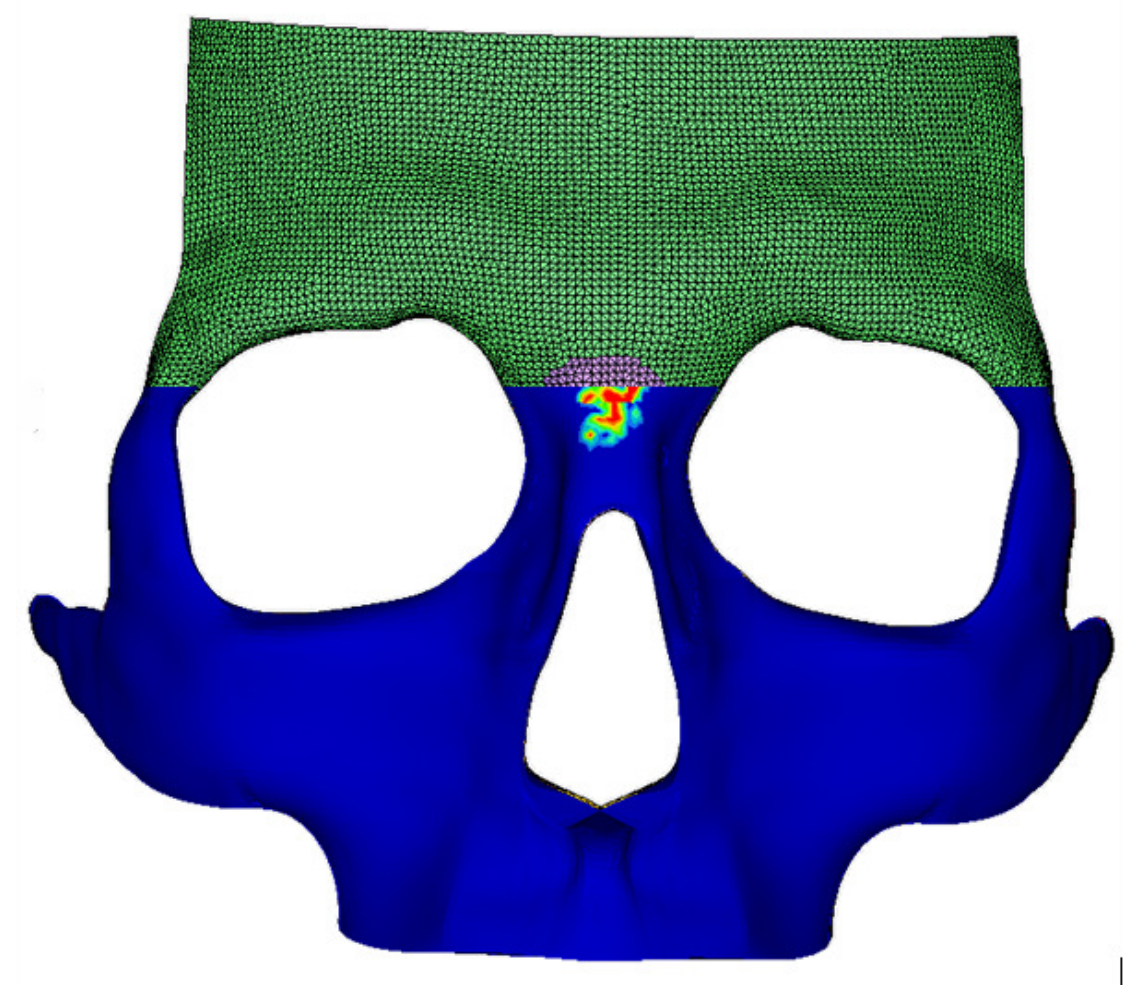

Figura 5.29 - Sobreposição da análise de tensão sobre o critério de falha, para o caso sem protetor, demonstrando que houve falha do osso nasal no instante observado $(9,1 \mu \mathrm{S})$ 


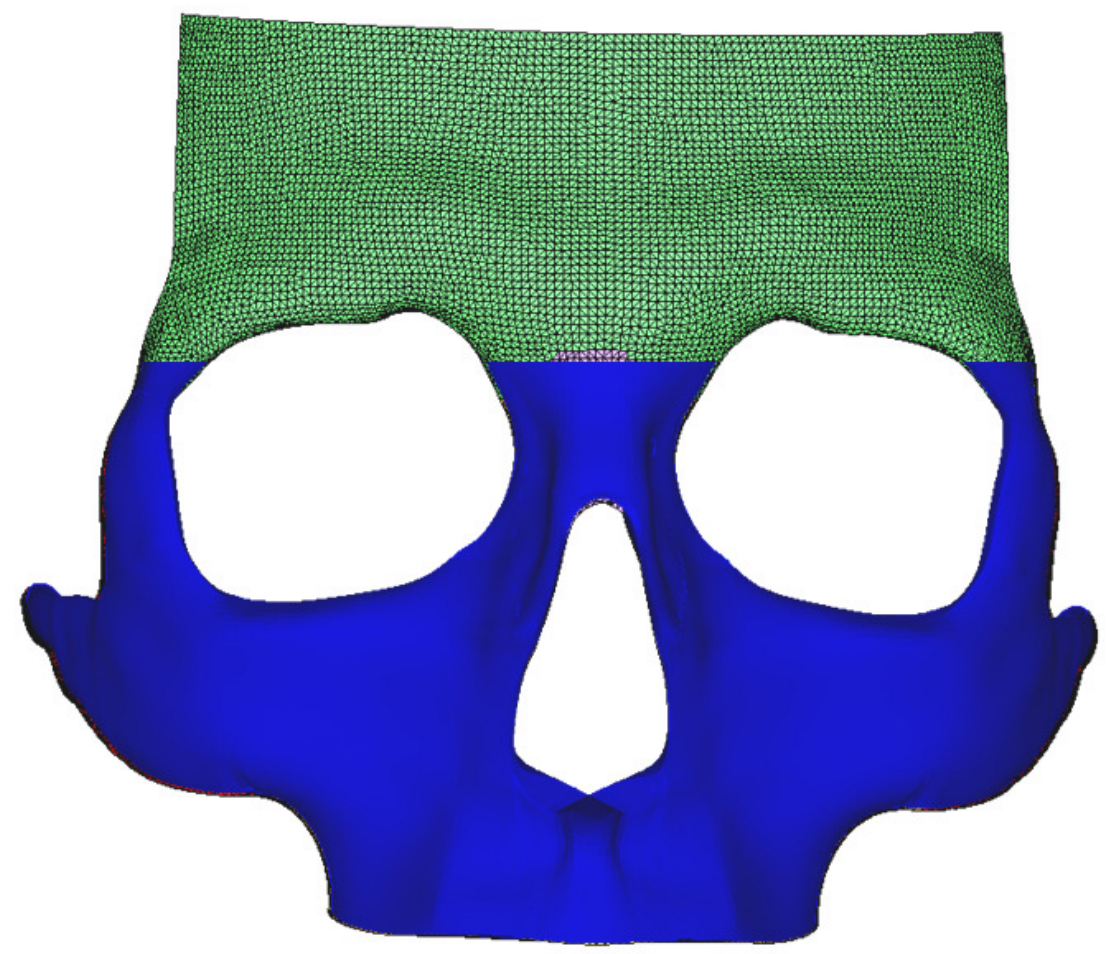

Figura 5.30 - Sobreposição da análise de tensão sobre o critério de falha, para o caso com protetor, demonstrando que não houve falha do osso nasal no instante observado $(9,1 \mu \mathrm{S})$
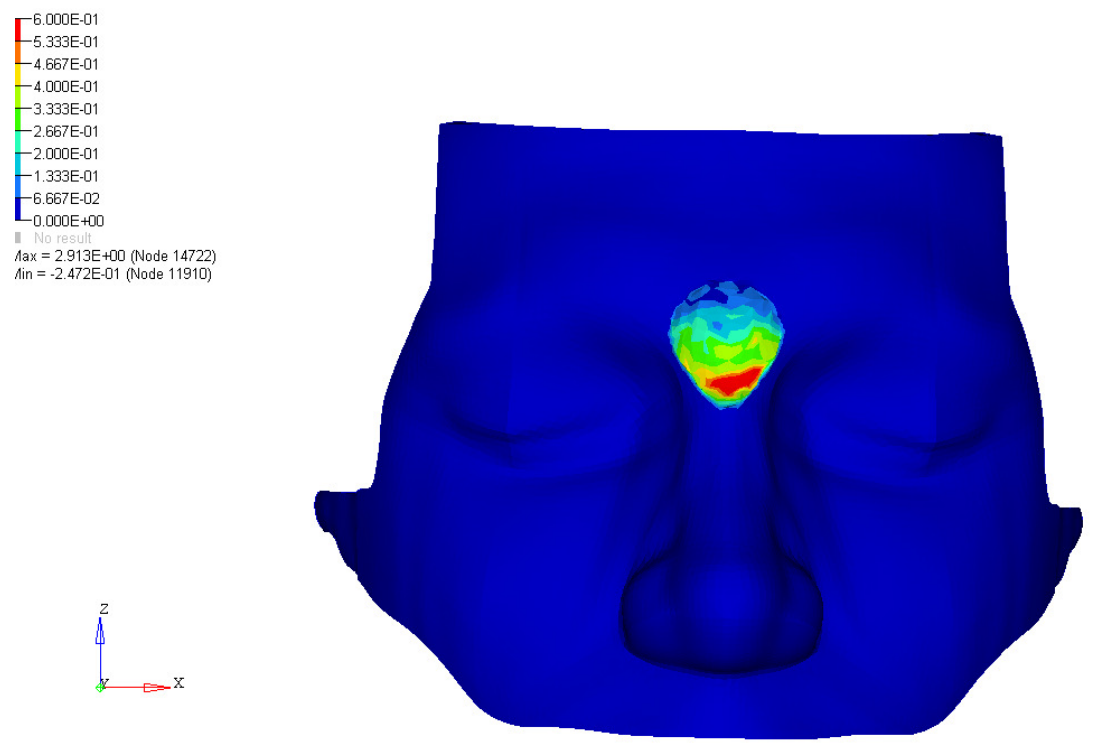

Figura 5.31 - Análise de tensão no tecido mole no instante crítico. Modelo facial sem protetor 

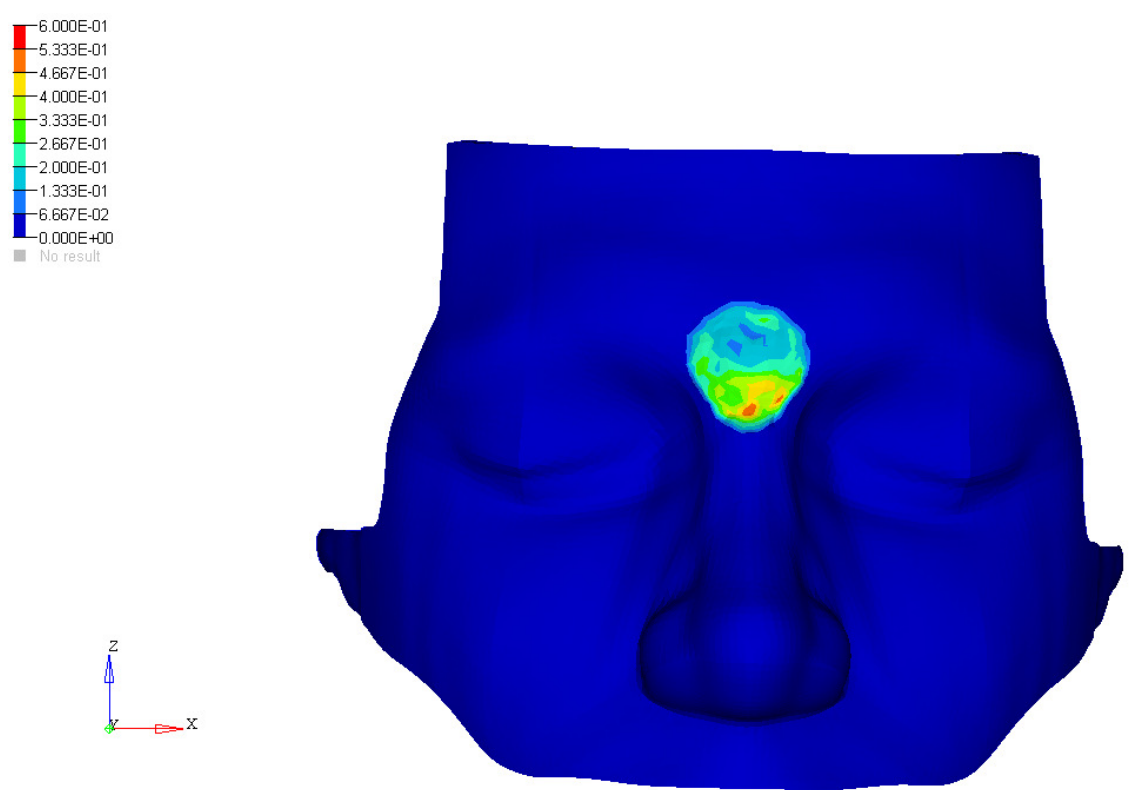

Figura 5.32 - Análise de tensão no tecido mole no instante crítico. Modelo facial com protetor nasal P1

Os resultados das figuras 5.31 e 5.32 mostram ainda a influência do protetor nasal na prevenção de injúrias nos tecidos moles da face através de sua capacidade amortecedora.

O perfil de pressão apresentado abaixo, mostra as análises da porção rígida do EVA (Figura 5.33) e da porção flexível do EVA na figura 5.4. 

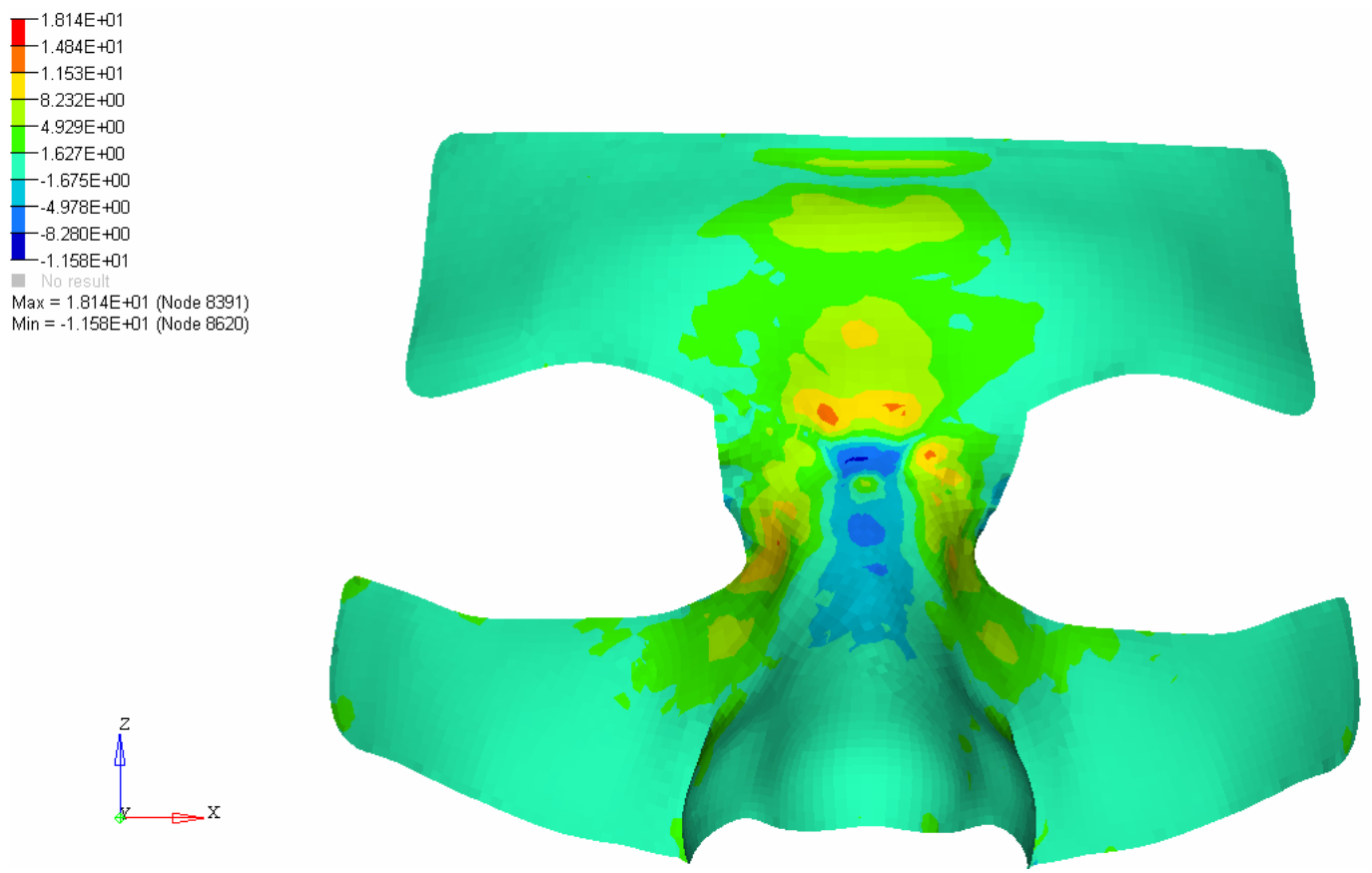

Figura 5.33 - Porção rígida do protetor nasal no instante $9,1 \mu \mathrm{s}$
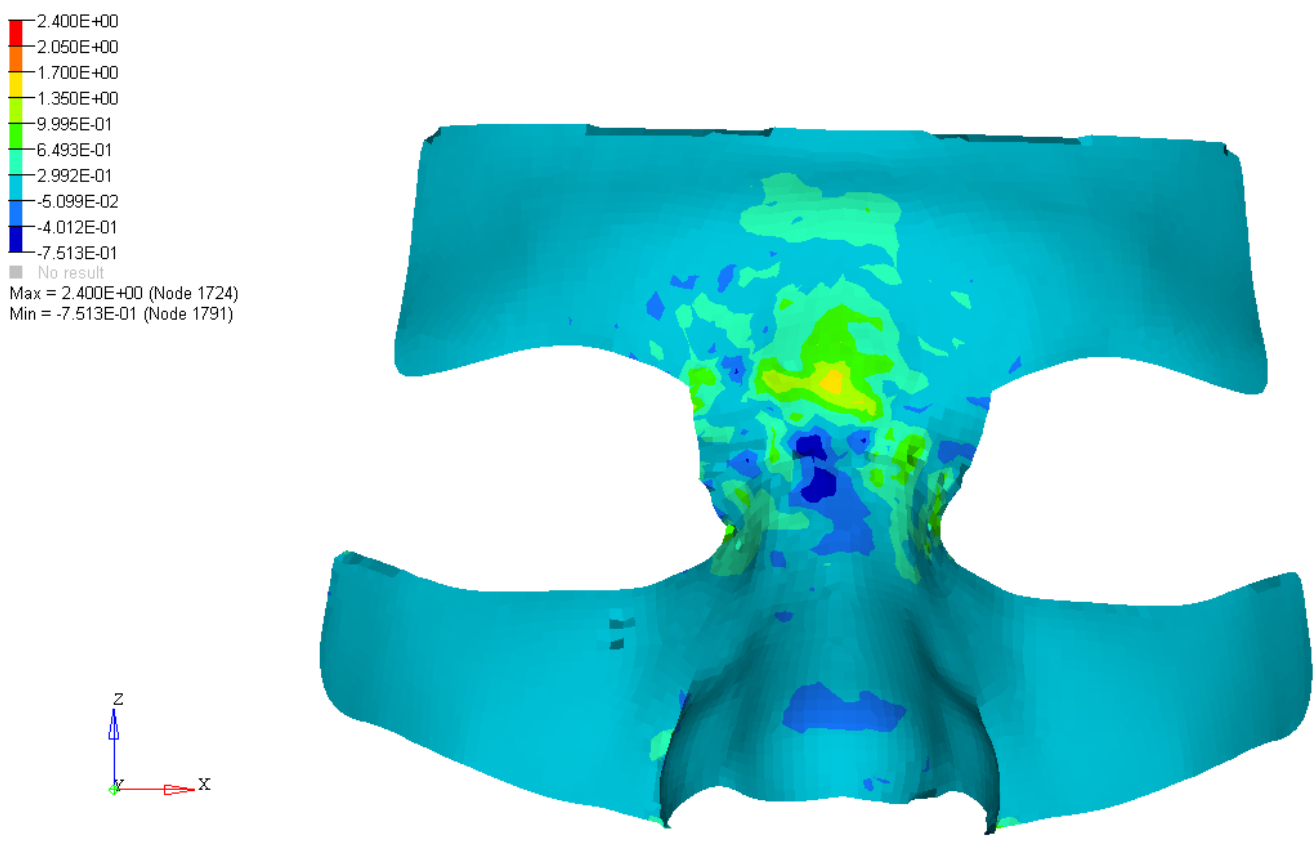

Figura 5.34 - Análise porção flexível do protetor nasal no instante $9,1 \mu \mathrm{s}$ 


\section{DISCUSSÃO}

Por se tratar de um trabalho pioneiro, houve a necessidade de se construir um modelo de protetor nasal piloto (item 5.2) para detectar pretensas falhas e erros nas simulações. Procurou-se a geometria mais simples, só do protetor $\mathrm{P} 1$, simulando apenas o EVA flexível, e o tecido mole e osso foram representados sem variação de espessura. As simulações foram feitas com o auxílio de uma bola com pequenas dimensões e rígida, chamada também de projétil, para facilitar o entendimento do fenômeno sem a necessidade de seu modelamento e ainda não gerar aumento no tempo computacional. O modelo piloto é mais simples, porém apresentou resultados satisfatórios.

O modelo final, muito mais complexo, apresentou variação de espessura da porção óssea e do tecido mole, respeitando as medidas tomográficas. Foi introduzido o protetor completo, uma lâmina de EVA flexível sobreposta por uma lâmina de EVA rígida, como mostra a figura 5.10, bem como as restrições e contatos, trazendo uma gama de informações e cálculos. A geometria do modelo final apresenta todas as particularidades da face, caracterizando suas zonas de resistência e fragilidade.

Nos itens 4.2 e 4.3, a caracterização do EVA flexível e rígido mostrou comportamentos bem distintos, apesar de o material ser o mesmo. Essa é uma característica particular dos polímeros. A diferença apareceu claramente na resposta ao impacto, dada por cada parte do protetor nasal (flexível e rígido), como ilustram as figuras 5.33 e 5.34. O EVA rígido reduziu a velocidade de impacto, pois deformou-se pouco. O EVA flexível aumentou o intervalo de tempo do impulso (vide 
Apêndice A), diminuindo, portanto, a intensidade da força transmitida ao osso. Além disso, esse material dissipa energia em forma de calor, porém, esse fenômeno não foi considerado nas análises numéricas realizadas neste trabalho. Com esses dados pode-se afirmar que o protetor nasal aqui estudado aproveita as características do material, pois a parte rígida se deforma pouco e desacelera o impacto enquanto a porção flexível se deforma bastante, distribui e absorve a energia recebida em um maior tempo.

$\mathrm{Na}$ análise em elementos finitos, o critério de falha do osso admitido neste trabalho foi o da tensão máxima principal. Foi adotado aqui o valor crítico encontrado na literatura de 0,13 MPa. Adotando para o osso esse critério de falha juntamente com o modelo elástico linear, os valores obtidos para tensão máxima foram maiores que os encontrados na literatura. Essa diferença é justificada por vários motivos: consideração do osso como material homogêneo elástico linear, valor do seu módulo de elasticidade aqui considerado (valor médio encontrado na literatura), além das imprecisões dos ensaios experimentais de onde os dados foram extraídos.

Apesar de artigos atuais sugerirem o uso da máxima deformação como critério de falha do osso, resultados diferentes dos obtidos neste trabalho seriam possíveis somente com modelos de materiais mais elaborados que o modelo elástico linear aqui utilizado.

As análises do modelo final, obtido através de tomografia computadorizada, apresentaram tempo computacional elevado; cada análise durou aproximadamente dez dias. Isso ocorreu devido ao grande número de elementos, modelo não linear dos materiais (tecido mole e EVAs) e contato entre as diversas camadas. Por esse motivo o material e a geometria do projétil foram limitados, respectivamente, como rígido e de pequenas dimensões. 
A AEF mostrou a capacidade do EVA em proteger os tecidos faciais. Além disso, é uma importante ferramenta a ser utilizada na otimização de um protetor nasal e na análise de situações críticas, como por exemplo, limite de aplicabilidade do protetor, no que se refere à velocidade máxima de impacto do projétil. Porém, nesse caso, situações reais de competição devem ser modeladas, e serão consideradas nas próximas pesquisas deste grupo. 


\section{CONCLUSÃO}

Baseando-se em simulações numéricas onde os parâmetros do EVA foram obtidos em ensaios de laboratório, e do osso e tecido mole foram retirados da literatura, pode-se concluir que:

- O protetor proposto mostrou-se eficiente na proteção dos ossos nasais em caso de impacto, confirmando assim a hipótese deste trabalho. 


\section{REFERÊNCIAS ${ }^{1}$}

1. Antoun JS, Lee KH. Sports-related maxillofacial fractures over an 11-year period. J Oral Maxillofac Surg. 2008 Mar;66(3):504-8.

2. Linn EW, Vrijhoef MM, de Wijn JR, Coops RP, Cliteur BF, Meerloo R. Facial injuries sustained during sports and games. J Maxillofac Surg. 1986 Apr;14(2):83-8.

3. Frenguelli A, Ruscito P, Bicciolo G, Rizzo S, Massarelli M. Head and neck trauma in sporting activities. Review of 208 cases. J Craniomaxillofac Surg. 1991. May;19(4):178-81.

4. Carroll SM, Jawad MA, West M, O'Connor TP. One hundred and ten sports related facial fractures. Br J Sports Med. 1995 Sep;29(3):194-5.

5. Flanders RA, Bhat M. The incidence of orofacial injuries in sports: a pilot study in Illinois. J Am Dent Assoc. 1995 Apr;126(4):491-6.

6. Levin L, Friedlander LD, Geiger SB. Dental and oral trauma and mouthguard use during sport activities in Israel. Dent Traumatol. 2003 Oct;19(5):237-42.

7. Garza JR, Baratta RV, Odinet K, Metzinger S, Bailey D, Best R, et al. Impact tolerances of the rigidly fixated maxillofacial skeleton. Ann Plast Surg. 1993 Mar;30(3):2126.

8. Ellis E, 3rd, Kittidumkerng W. Analysis of treatment for isolated zygomaticomaxillary complex fractures. J Oral Maxillofac Surg. 1996 Apr;54(4):386-400; discussion -1.

9. Cascone P, Petrucci B, Ramieri V, Marianetti TM. Security Hi-tech Individual Extralight Device Mask: a new protection for [soccer] players. J Craniofac Surg. 2008 May;19(3):772-6.

${ }^{1}$ De acordo com o Estilo Vancouver. Abreviatura de periódicos segundo base de dados MEDLINE. 
10. Ranalli DN, Demas PN. Orofacial injuries from sport: preventive measures for sports medicine. Sports Med. 2002;32(7):409-18.

11. Kaplan S, Driscoll CF, Singer MT. Fabrication of a facial shield to prevent facial injuries during sporting events: a clinical report. J Prosthet Dent. 2000 Oct;84(4):387-9.

12. McIntosh AS, McCrory P. Preventing head and neck injury. Br J Sports Med. 2005 Jun;39(6):314-8.

13. McIntosh L, Cordell JM, Wagoner Johnson AJ. Impact of bone geometry on effective properties of bone scaffolds. Acta Biomater. 2009 Feb;5(2):680-92.

14. Westerman B, Stringfellow PM, Eccleston JA, Harbrow DJ. Effect of ethylene vinyl acetate (EVA) closed cell foam on transmitted forces in mouthguard material. Br J Sports Med. 2002 Jun;36(3):205-8.

15. Coto NP. Estudo do comportamento mecânico de protetores bucais para esporte confeccionados em copolímero de etileno e acetato de vinila (EVA): modelo experimental de arcos dentais obtidos em epóxi [Dissertação de Mestrado].São Paulo: Faculdade de Odontologia da USP; 2006.

16. Ruan JS, Khalil T, King AI. Dynamic response of the human head to impact by threedimensional finite element analysis. J Biomech Eng. 1994 Feb;116(1):44-50.

17. Delaney JS, Al-Kashmiri A, Drummond R, Correa JA. The effect of protective headgear on head injuries and concussions in adolescent football (soccer) players. Br J Sports Med. 2008 Feb;42(2):110-5; discussion 5.

18. Chao MT, Paletta C, Garza JR. Facial Trauma, Sports- Related Injuries. Medscape J Med. 2008;1:1-14.

19. Higuera S, Lee EI, Cole P, Hollier LH, Jr., Stal S. Nasal trauma and the deviated nose. Plast Reconstr Surg. 2007 Dec;120(7 Suppl 2):64S-75S.

20. Stanley RB, Jr., Nowak GM. Midfacial fractures: importance of angle of impact to horizontal craniofacial buttresses. Otolaryngol Head Neck Surg. 1985 Apr;93(2):186-92.

21. Dingman RO, Natvig P. Cirurgia das Fraturas Faciais.São Paulo: Editora Santos; 2001. p.267-94. 
22. Follmar KE, Baccarani A, Das RR, Erdmann D, Marcus JR, Mukundan S. A clinically applicable reporting system for the diagnosis of facial fractures. Int J Oral Maxillofac Surg. $2007 \mathrm{Jul} ; 36(7): 593-600$.

23. Morita R, Shimada K, Kawakami S. Facial protection masks after fracture treatment of the nasal bone to prevent re-injury in contact sports. J Craniofac Surg. 2007 Jan;18(1):143-5.

24. Crow RW. Diagnosis and management of sports-related injuries to the face. Dent Clin North Am. 1991 Oct;35(4):719-32.

25. Heise M, Eufinger $\mathrm{H}$. Individueller Gesichtsschutz nach frakturversonrgung am nasenbein und jochbogen bei profifuBballern. Mund Kiefer GesichtsChir. 2001;5:320-22.

26. Delilbasi C, Yamazawa M, Nomura K, Iida S, Kogo M. Maxillofacial fractures sustained during sports played with a ball. Oral Surg Oral Med Oral Pathol Oral Radiol Endod. 2004 Jan;97(1):23-7.

27. Rontal E, Rontal M. Maxillofacial injuries in football players: an evaluation of current facial protection. J Sports Med Phys Fitness. 1971 Dec;11(4):241-5.

28. Hampson D. Facial injury: a review of biomechanical studies and test procedures for facial injury assessment. J Biomech. 1995 Jan;28(1):1-7.

29. Hodgson VR. Tolerance of the facial bones to impact. Am J Anat. 1967;120:113-22.

30. Welbourne ER, Ramet M, Zarebski MA. A comparison of facial fracture tolerance with the performance of a surrogates test device. Proc 12th experimental safety vehicle conf1989.

31. Le Fort R. Êtude experimentale sur les fractures de la machoire superieure. Rev de Chir. 1901;23:208-306.

32. King AI. Progress of research on impact biomechanics. J Biomech Eng. 1993

Nov;115(4B):582-7. 
33. Withnall C, Shewchenko N, Gittens R, Dvorak J. Biomechanical investigation of head impacts in football. Br J Sports Med. 2005 Aug;39 Suppl 1:i49-57.

34. Verschueren P, Delye H, Depreitere B, Van Lierde C, Haex B, Berckmans D, et al. A new test set-up for skull fracture characterisation. J Biomech. 2007;40(15):3389-96.

35. Welbourne ER, Ramet M, Zarebski M. A comparison of facial fracture tolerance with the performance of a surrogates test device. Proc 12th experimental safety vehicle conf 1989 .

36. McIntosh AS, McCrory P. Impact energy attenuation performance of football headgear. Br J Sports Med. 2000 Oct;34(5):337-41.

37. Kim HS, Shafig RM. Model For Thickness Effect With Impact Testing Of Viscoelastic Material. J Appl Polymer Scien. 2001;81:1762-7.

38. Haug SP, Haug RH. Fabrication of a facial orthotic for protection of a fractured nose. $\mathbf{J}$ Oral Maxillofac Surg.1992 Jul;50(7):765-6.

39. Brown NL, House K, Leach A, Page K, Irvine GH, Sandy JR. A paralleling device and ethylene vinyl acetate baffles for use with mandibular distraction osteogenesis: technical note. J Orthod. 2004 Sep;31(3):181-9.

40. Mendel DA, Ucar Y, Brantley WA, Rashid RG, Harrell SL, Grentzer TH. Impact energy absorption of three mouthguard materials in an aqueous environment. Dent Traumatol. 2009 Feb;25(1):130-5.

41. Kosmopoulos V, Schizas C, Keller TS. Modeling the onset and propagation of trabecular bone microdamage during low-cycle fatigue. J Biomech. 2008;41(3):515-22.

42. Snedeker JG, Bajika M, Hug JM, Székely G, Niederer P. The creation of high-fidelity finite element model of the kidney for use in trauma research. J Visual Comput Animat. 2002; $13: 53-84$.

43. Witzel U, Preuschoft H. Finite-element model construction for the virtual synthesis of the skulls in vertebrates: case study of Diplodocus. Anat Rec A Discov Mol Cell Evol Biol. 2005 Apr;283(2):391-401. 
44. Hallquist J. LS-DYNA Keyword user's Manual - Version 970. Livermore, California (EUA): Livermore Software Technology Corporation - LSTC. 2003:1564p.

45. Verdejo R, Mills NJ. Heel-shoe interactions and the durability of EVA foam runningshoe midsoles. J Biomech. 2004 Sep;37(9):1379-86.

46. Aerts P, Ker RF, De Clercq D, Ilsley DW, Alexander RM. The mechanical properties of the human heel pad: a paradox resolved. J Biomech. 1995 Nov;28(11):1299-308.

47. Schileo E, Taddei F, Cristofolini L, Viceconti M. Subject-specific finite element models implementing a maximum principal strain criterion are able to estimate failure risk and fracture location on human femurs tested in vitro. J Biomech. 2008;41(2):356-67.

48. Park MS, Levy ML. Biomechanical aspects of sports-related head injuries. Neurol Clin. 2008 Feb;26(1):33-43; vii.

49. Anderson AE, Ellis BJ, Maas SA, Peters CL, Weiss JA. Validation of finite element predictions of cartilage contact pressure in the human hip joint. J Biomech Eng. 2008 Oct;130(5):051008.

50. Lotti RM, Machado AW, Mazzieiro ET; LandreJr J. Aplicabilidade científica do método dos elementos finitos. Dental Press Ortodont Ortop Facial. 2006;11(2):35-43.

51. Keller TS. Predicting the compressive mechanical behavior of bone. J Biomech. 1994 Sep;27(9):1159-68.

52. Field C, Ichim I, Swain MV, Chan E, Darendeliler MA, Li W, et al. Mechanical responses to orthodontic loading: a 3-dimensional finite element multi-tooth model. Am $\mathrm{J}$ Orthod Dentofacial Orthop. 2009 Feb;135(2):174-81.

53. Rincon-Kohli L, Zysset PK. Multi-axial mechanical properties of human trabecular bone. Biomech Model Mechanobiol. 2009 Jun;8(3):195-208.

54. Wang F, Lee HP, Lu C. Effects of head size and morphology on dynamic responses to impact loading. Med Biol Eng Comput. 2007 Aug;45(8):747-57. 
55. Gefen A, Megido-Ravid M, Itzchak Y. In vivo biomechanical behavior of the human heel pad during the stance phase of gait. J Biomech. 2001 Dec;34(12):1661-5.

56. Mazza E, Papes O, Rubin MB, Bodner SR, Binur NS. Nonlinear elastic-viscoplastic constitutive equations for aging facial tissues. Biomech Model Mechanobiol. 2005 Nov;4(23):178-89.

57. Gerard JM, Ohayon J, Luboz V, Perrier P, Payan Y. Non-linear elastic properties of the lingual and facial tissues assessed by indentation technique. Application to the biomechanics of speech production. Med Eng Phys. 2005 Dec;27(10):884-92.

58. Holberg C, Heine AK, Geis P, Schwenzer K, Rudzki-Janson I. Three-dimensional soft tissue prediction using finite elements. Part II: Clinical application. J Orofac Orthop. 2005 Mar;66(2):122-34.

59. Zahouani H, Pailler-Mattei C, Sohm B, Vargiolu R, Cenizo V, Debret R.

Characterization of the mechanical properties of a dermal equivalent compared with human skin in vivo by indentation and static friction tests. Skin Res Technol. 2009 Feb;15(1):68-76.

60. Miller K, Chinzei K. Constitutive modelling of brain tissue: experiment and theory. $\mathrm{J}$ Biomech. 1997 Nov-Dec;30(11-12):1115-21.

61. EEVC. European Parliament and of the Council relating to the protection of pedestrians and other vulnerable road users before and in the event of a collision with a motor vehicle and amending Directive 70/156/EEC. Official J European Union, L 31, 422004;4(2):21.

62. Bonet J, Wood RD. Non-linear continuum mechanics for finite element analysis.Cambrigde: Cambridge University Press; 1997. Sect. 248 p.

63. Handbook Es. Coefficients of friction - Many material compared. 2006. 
Apêndice A - Definições físicas necessárias para o entendimento do fenômeno impacto

O impacto de dois corpos envolve uma violenta mudança no movimento causada por forças que atuam em um intervalo de tempo muito curto, que vai do instante em que os corpos entram em contato até o instante em que eles se separam. A figura A.1 ilustra o impacto de uma bola com o solo.

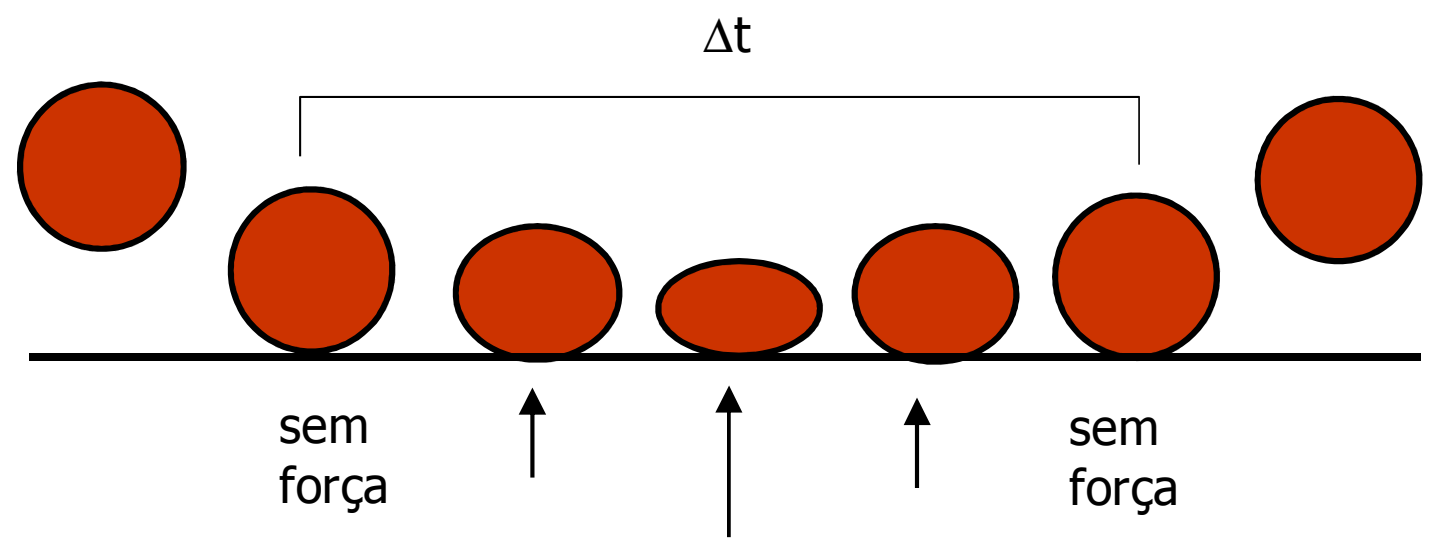

Figura A.1 - Impacto de uma bola com o solo, ocorrendo em um intervalo de tempo $\Delta t$

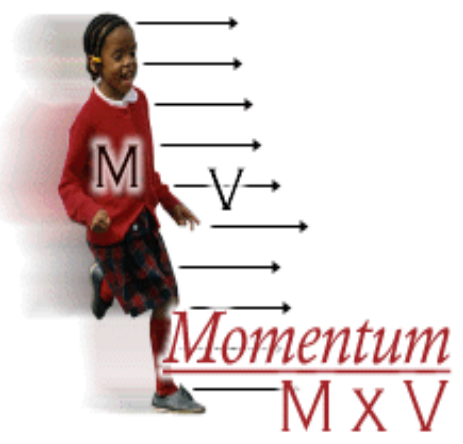

\section{Momento linear}

Momento linear é a tendência de um objeto em movimento em certa direção se manter em movimento na mesma velocidade e direção. Matematicamente momento linear é o produto da massa do objeto por sua velocidade:

$$
p=m v
$$

Em um impacto há transferência de momento de um corpo a outro. 


\section{Segunda lei de Newton}

A taxa de mudança de momento de um corpo é proporcional à força aplicada naquele corpo e na direção da força.

$$
\begin{aligned}
& F=\frac{\Delta(m v)}{\Delta t} \\
& F \Delta t=m \Delta v=\Delta p
\end{aligned}
$$

\section{Impulso}

É a força multiplicada pelo intervalo de tempo:

$$
I=F \Delta t
$$

Impulso é a única maneira de transferir momento. Mantendo o momento a ser transferido constante, portanto, a intensidade da força aplicada depende do intervalo de tempo de contato do impacto. A figura A.2 ilustra o impacto entre uma bola de golfe e uma bola de baseball. 


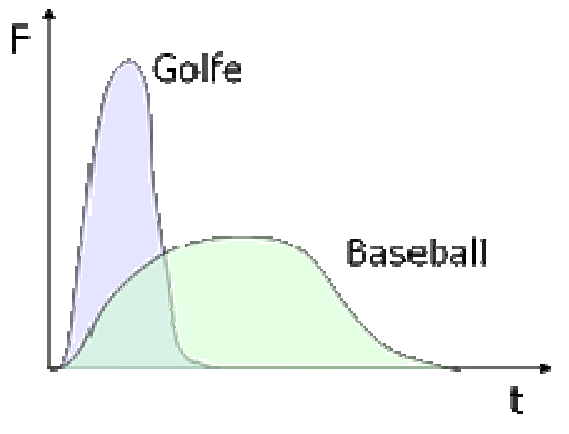

Bola de golfe è muito dua e nấo se deforma nuito durante o impacto, a curva de impulso é, portanto, muito curta e de alta intensidade.

Baseball è uma bola mais macia e, portanto, se deforma multo, ficando em contato com o taco de madeila por um periodo mais longo, levando a uma curva de impulso mais longa e menos intensa.

Figura A.2 - A intensidade da força F a ser transferida em um impacto depende do intervalo de tempo de contato entre os corpos impactantes 
Anexo A - Parecer do Comitê de Ética da FOUSP

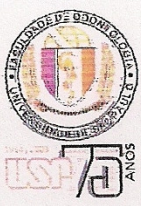

Unversidade de São Paulo

Faculdade de odontologla

comita de Etica cm Pesquisa

PARECER DE APROVAÇĀO

FR - 250929

Protocolo 25/2009

Com base em parecer de relator, o Comitê de Ética em Pesquisa APROVOU o protocolo de pesquisa "Avaliação de protetor nasal para atividades despornives: amálise por elementos fiñtos e estudo clínico" de responsabilidade do(a) Pesquisador(a) Neide Pena Coto, sob orientação do(a) Prof.(a) Br.(a) Josete Barbosa Cruz Meíra.

Tendo em vista a legislação vigente, devem ser encaminhados a este comitê relatórios anuais referentes ao andamento da pesquisa e ao término cópia do trabalho em "cd". Qualquer emenda do projeto original deve ser apresentada a este CEP para apreciação, de forma clara e sucinta, identificando a parte do protocolo a ser modificada e suas justificativas.

São Paulo, 11 de maio de 2009.

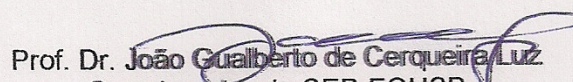
Coordenador do CEP-FOUSP 
Anexo B - Declaração de Parceria com o CTI Renato Archer

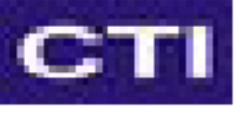

Centro de Tecnologia da Informação Renato Archer - CTI

Rodovia Dom Pedro I, km 143,6-Campinas - S.P.

CEP $13082-120$

Telefone: (0xx-19) 3746-6088/ Fax (0xx-19) 3746-6028

\section{DECLARAÇÂO}

Ao Comitê de Ética em Pesquisa

Departamento de Materiais Dentários

Faculdade de Odontologia da Universidade de São Paulo - FOUSP

Declaramos, a fim de viabilizar a execução do projeto de pesquisa "SIMULAÇẢO DE PROTETOR NASAL PARA ATIVIDADES DESPORTIVAS: ANÁLISE POR ELEMENTOS FINITOS E ESTUDO CLÍNICO", sob a responsabilidade dos pesquisadores Doutoranda Neide Pena Coto e Profa. Dra. Josete Barbosa Cruz Meira da FOUSP, que a Divisão de Tecnologias Tridimensionais (DT3D) do Centro de Tecnologia da Informação Renato Archer (CTI), instituto do Ministério da Ciência e Tecnologia, disponibiliza a sua estrutura laboratorial de aplicativos computacionais e de equipamentos, bem como o conhecimento dos seus pesquisadores que possam agregar valor ao referido projeto, para a sua plena execução.

Adicionalmente, segue em anexo termo de transferência de banco de dados de imagens que será utilizado neste projeto de pesquisa. O banco de dados foi cedido ao CTI para atividades de pesquisas pela Profa Dra Beatriz Silva Câmara Mattos da Faculdade de Odontologia da USP. Estes dados foram previamente utilizados em trabalho de mestrado sob sua orientação em cooperação com o CTI e previamente aprovado por Comitê de Ética desta Faculdade

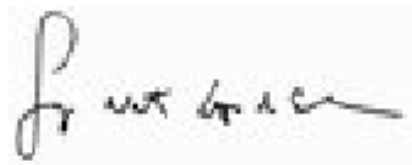

Jorge Vicente Lopes da Silva, Doutor em Engenharia

Chefe da Divisão de Tecnologias Tridimensionais - DT3D

Centro de Tecnologia da Informação Renato Archer - CTI

Ministério da Ciência e Tecnologia - MCT

Tel.: 19-3746-6142

E-mail: jorge.silva@cti.gov.br http://www.cti.gov.br/promed 
Anexo C - Termo de Transferência de Banco de Dados

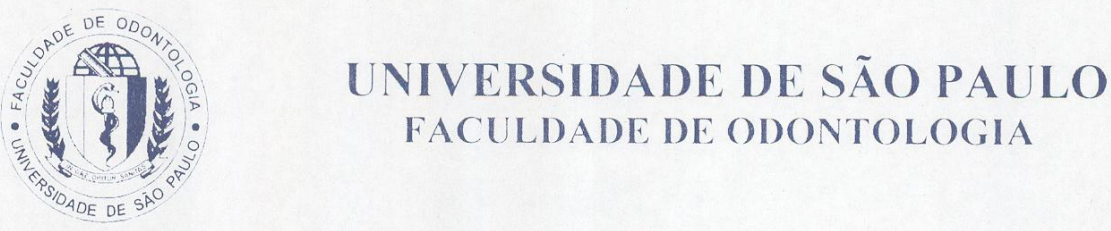

TERMO DE TRANSFERÊNCIA DE BANCO DE DADOS

Pelo presente TERMO DE TRANSFERÊNCIA O pesquisador responsável pelo Processo $n^{\circ}$ 06/03765-4 junto à FUNDAÇÃO DE AMPARO À PESQUISA DO ESTADO DE SÃO PAULO, Linha de Fomento - Auxílio Pesquisa - Regular, desenvolvido junto à instituição no 01001032 - Faculdade de Odontologia / Universidade de São Paulo, Profa. Dra. Beatriz Silva Câmara Mattos, transfere o Banco de Dados de Imagens constituído pelas imagens geradas no desenvolvimento do Trabalho de Pesquisa intitulado "ESTABILIDADE DIMENSIONAL EM PRÓTESE ÓCULO-PALPEBRAL CONFECCIONADA POR MEIO DE MODELO REVERSO OBTIDO PELO SISTEMA CAD/CAM" para O CENTRO DE PESQUISA RENATO ACHER - CENPRA, Ministério da Ciência e Tecnologia.

São Paulo, 15 de setembro de 2008.

$$
\text { Sfezualor. }
$$

Profa. Dra. Beatriz Silva Câmara Mattos

Av Prof.Lineu Prestes, 2227 - Cidade Universitára "Armando de Salles Oliveira" CFP 05508-000 São Paulo - SP - Diretoria Telefax: (011)3091-0062/3091-7817/3091-7860 - Compras (011) 3091-7825 